\title{
MAJOR IONS COMPOSITION OF THE GROUNDWATER AND SURFACE WATER SYSTEMS AND THEIR GEOLOGICAL AND GEOCHEMICAL CONTROLS IN THE ETHIOPIAN VOLCANIC TERRAIN
}

\author{
Tenalem Ayenew \\ Department of Geology and Geophysics, Addis Ababa University, PO Box 1176 \\ Addis Ababa, Ethiopia. E-mail: Tenalema@geol.aau.edu.et
}

\begin{abstract}
Broad hydrochemical survey has been carried out to study the spatial variation of the major ions composition of the surface and groundwater systems in the Ethiopian volcanic terrain and associated Plio-Quaternary sediments. The result revealed wide hydrochemical variations controlled by geological, geochemical, geomorphological and climatological factors. The total ionic concentration increases dramatically from the highlands towards the rift valley following the regional groundwater flow directions to low-lying regions characterized by low annual rainfall and high evapotranspiration. In the rift the total dissolved solids (IDS) variation is dramatic (in places more than 50 fold). The highland waters are predominantly fresh with low total ionic concentrations, TDS varying often from 50 to $1200 \mathrm{mg} / \mathrm{l}$; with dominant ions of $\mathrm{Ca}, \mathrm{Mg}$ and $\mathrm{HCO}_{3}$. The rift valley waters have very high TDS (varying in a wide range between 200 and 73,015 mg/l) characterized by high $\mathrm{Na}$ and $\mathrm{HCO}_{3}$, in places highly enriched with F. Waters of the southern and central Main Ethiopian Rift (MER) are dominated by $\mathrm{HCO}_{3}$ tending to $\mathrm{SO}_{4}$ and $\mathrm{Cl}$ type in northern and central Afar mainly due to changes in lithology related to evaporite deposits and due to the natural chemical evolution of waters as they move from highland recharge to low-lying rift discharge areas. Deep geothermal waters, alkaline terminal lakes of the MER and small highly evaporated saline and brackish lakes of the Afar have the highest ionic concentrations.
\end{abstract}

Key words/phrases: Ethiopian rift, hydrogeology, ionic concentration, TDS, volcanic terrain

\section{INTRODUCTION}

The chemical composition of natural waters and the amount of its ionic species depend on several factors: type of soil and rock through which the water passes, the degree of weathering and solubility of the mineral components of the rocks and soils, the extent and duration of the contact with rocks and soils, the temperature conditions, the type of dissolved and suspended solutes that falls with precipitation.

Climatic pattern, which produces characteristics plant communities and soil types governing biochemical processes in the hydrosphere, play also important role. The process of rock weathering is strongly influenced by temperature and the amount and distribution of precipitation. Aside from the recharge and discharge conditions related to precipitation; the evaporation of open water bodies influence the amount of the total ionic concentrations. Climatic patterns tend to produce characteristics plant communities and soil types, and the composition of waters of streams draining such areas could be influenced by the ecological balance. Bicarbonate, for example, tends to predominate in water in areas where vegetation grows profusely.
A major impact of the environmental factors influencing the composition of water may also come from human activities. Solutes may be directly added to water by disposal of municipal and industrial wastes and from application of fertilizers.

The number of major dissolved constituents in water is quite few, and the natural variations are not as great as might be expected from a study of the various minerals and organic materials through which the water has passed. More than ninety percent of the dissolved solids in groundwater can be attributed to eight ions: sodium $(\mathrm{Na})$, calcium $(\mathrm{Ca})$, potassium $(\mathrm{K})$, magnesium $(\mathrm{Mg})$, sulfate $\left(\mathrm{SO}_{4}\right)$, chloride $(\mathrm{Cl})$, bicarbonate $\left(\mathrm{HCO}_{3}\right)$ and carbonate $\left(\mathrm{CO}_{3}\right)$ (Freeze and Cherry, 1979). These ions are usually present at concentrations greater than 1 milligram per litre $(\mathrm{mg} / \mathrm{l})$. Silica $\left(\mathrm{SiO}_{2}\right)$, a non-ionic species and nitrate $\left(\mathrm{NO}_{3}\right)$ are also typically present at concentrations greater than $1 \mathrm{mg} / \mathrm{l}$. There are, however, many naturally occurring ions as minor and trace constituents usually present at concentrations of less than $0.1 \mathrm{mg} / \mathrm{l}$. Some of the common ones at times contribute to major ions include fluoride $(F)$, boron (B), iron (Fe), strontium (St), etc. These ions and other trace elements are important indicators of the origin and movement of surface water and 
groundwater systems. Many other inorganic constituents are valuable from a standpoint of water quality.

In this paper, the major ion chemistry of natural waters in the volcanic terrains and associated PlioQuaternary sediments of Ethiopia is addressed. The main objective of the work is to provide the spatial variation of the hydrochemistry of natural waters in relation to the geomorphological setting and lithological variations. Particular emphasis is given to the geological and geochemical factors that influence the major ion composition of the groundwater and surface waters situated in highly variable climatic conditions. Distinction is made among the major physiographic regions: the rift valley, the transitional escarpment and the highlands.

\section{DESCRIPTION OF THE STUDY AREA}

\section{Physiography and climate}

The major physical features of Ethiopia are the results of the extensive and spectacular uplifting and faulting which cracked the old crystalline block of the African continent forming the rift valley. The uplifting and volcanism produced the high plateau, which stand at a general elevation of between 2000 and 2500 m.a.s.l (Mohr, 1983). Volcanic activity resulted in the building up of higher mountain areas now dominate the plateau surfaces in several regions, such as the Simen Mountain massif, which rises to 4620 meters above sea level (m.a.s.l). The Ethiopian rift stretches from northern Afar to the south up to the border of Kenya (Fig. 1.). The rift separates the highlands, which occupy the eastern and western elevated part of the country gradually descending to the east and west. The plateaux are separated from the rift by well-defined faulted escarpments. There are smaller troughs and sinks in the rift as well. The most notable is the Kobar sink (110 m below sea level) close to Lake Afdera in northern Afar. The Ethiopian relief includes, therefore, a range of altitudes stretching from below sea level to 4620 m.a.s.l. Within these extremes, about $50 \%$ of the land surface is above the 1500 meters contour line.

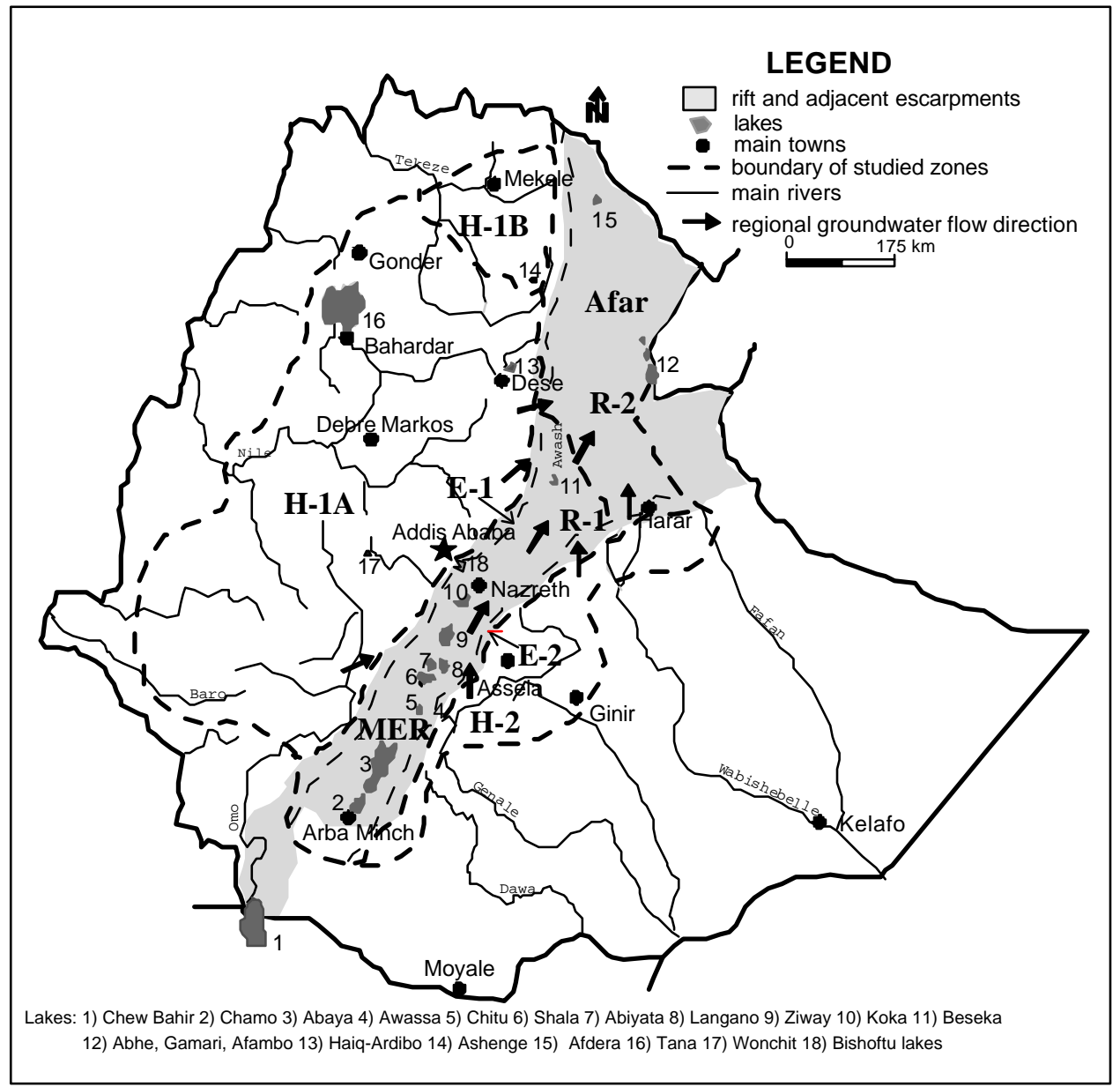

Fig 1 Location map. 
The Pluvial Periods were responsible for the further shaping of the Ethiopian landscape, and produced the deep gorges, which have dissected the high plateau lands (Street, 1979). The Central regions are most characteristics of this plateau-andgorge landscape where the beds of major rivers are often 2000 meters below the general level of the plateau surface, and where the hard basalt layers have resulted in abrupt edges of the gorges, overlooking a series of lower terraces which mark the underlying layers of relatively softer Mesozoic sedimentary sequences. The major rivers in the studied region drain through these deep gorges in different directions.

The rift valley is characterized by the occurrence of many alkaline and fresh lakes occupying volcano-tectonic depressions. On the highlands there are a number of crater lakes including Lake Tana, the largest in the country. The Awash River, draining through the rift floor and ending terminally at Lake Abhe, forms the central sector of the studied area. Many of the lakes are confined within the MER starting from Lake Chamo to the south up to Lake Ziway to the north.

As in topography, the Ethiopian climate is highly variable. The south-western region receives the heaviest rainfall. The mean annual rainfall is about $1500 \mathrm{~mm}$, but it is much higher in specific locations, in places as high as $2800 \mathrm{~mm}$ (EMA, 1988). The western low-lying regions receive over 1000 mm mean annual rainfall gradually decreasing towards the northeast and east. In central and north central Ethiopia, the annual rainfall is around $1100 \mathrm{~mm}$. In south-eastern Ethiopia, the mean annual rainfall is about $700 \mathrm{~mm}$, but this amount varies from over 1200 in parts of Sidama Zone to less than $400 \mathrm{~mm}$ over most of the Ogaden. The rainfall in the rift varies widely from around 700 in the central MER to less than $400 \mathrm{~mm}$ in much of the Afar depression.

The land surface rises gradually and considerably towards the interior aulminating in mountain peaks in different parts of the country. Thus temperature, as it is affected by altitude, decreases towards the interior. Mean annual temperature varies from over $30^{\circ} \mathrm{C}$ in tropical lowlands to less than $10^{\circ} \mathrm{C}$ at very high altitudes. Ethiopia is a country where extremes of temperature are experienced.

\section{Geology}

The complex spatial and temporal distribution of the volcanic rocks, their different reciprocal stratigraphic relationships with the Mesozoic and Precambrian rocks and recent Plio-Quaternary sediments, their wide compositional, structural and textural variability, their different level of weathering and variable topographic position diversified the hydrogeological behaviour of the volcanic rocks and influence the hydrochemical signature of natural waters.

A comprehensive and simplified stratigraphy of the Ethiopian volcanic terrain is given by Zanettin (1993). A more detailed account of flood basalts of the north-western plateau is given by Pik et al. (1998). The Ethiopian volcanics can be divided into two main series: Trap Series and Rift Series. Much of the volcanic province is dominated by Tertiary basaltic flows, fed from fissures aligned along developing pairs of opposed, emerging continental margins. The volcanics are distributed asymmetrically about the Ethiopian rift system (Fig. 2). The asymmetry matches that of the eastern uplifted highlands, comprising the broad western plateau and the narrow south-eastern plateau to either side of the rift. The thick sequence of the Trap Series flood basalts are superimposed by thick lava flows emanating from central volcanoes forming shield volcanic mountains. In places the thickness reaches more than $1500 \mathrm{~m}$. The subdivisions of Trap Series volcanics include the following.

Ashanghe Group - consists of basaltic lava flows with interbedded pyroclastics, ignimbrite and rhyolite at the top with tuffaceous materials containing lacustrine deposits and lignite seams. Dolerite sills, acidic dikes and other intrusions are common.

Aiba and Alaji fissural volcanism - represents the emission of huge volumes of transitional homogeneous basalt interlayered with silicic rocks. In north-eastern plateau (Tigray and Wollo) it occurs only close to the rift escarpment. They are the dominant units in the eastern plateau of Arsi and Bale regions.

Termaber central volcanism (Miocene) - built up large shield volcanoes mainly in the central part of the western plateau and adjacent to the western escarpment. It decreases in age from north to south changing in composition from transitional to alkaline type of basalt in the same direction. 


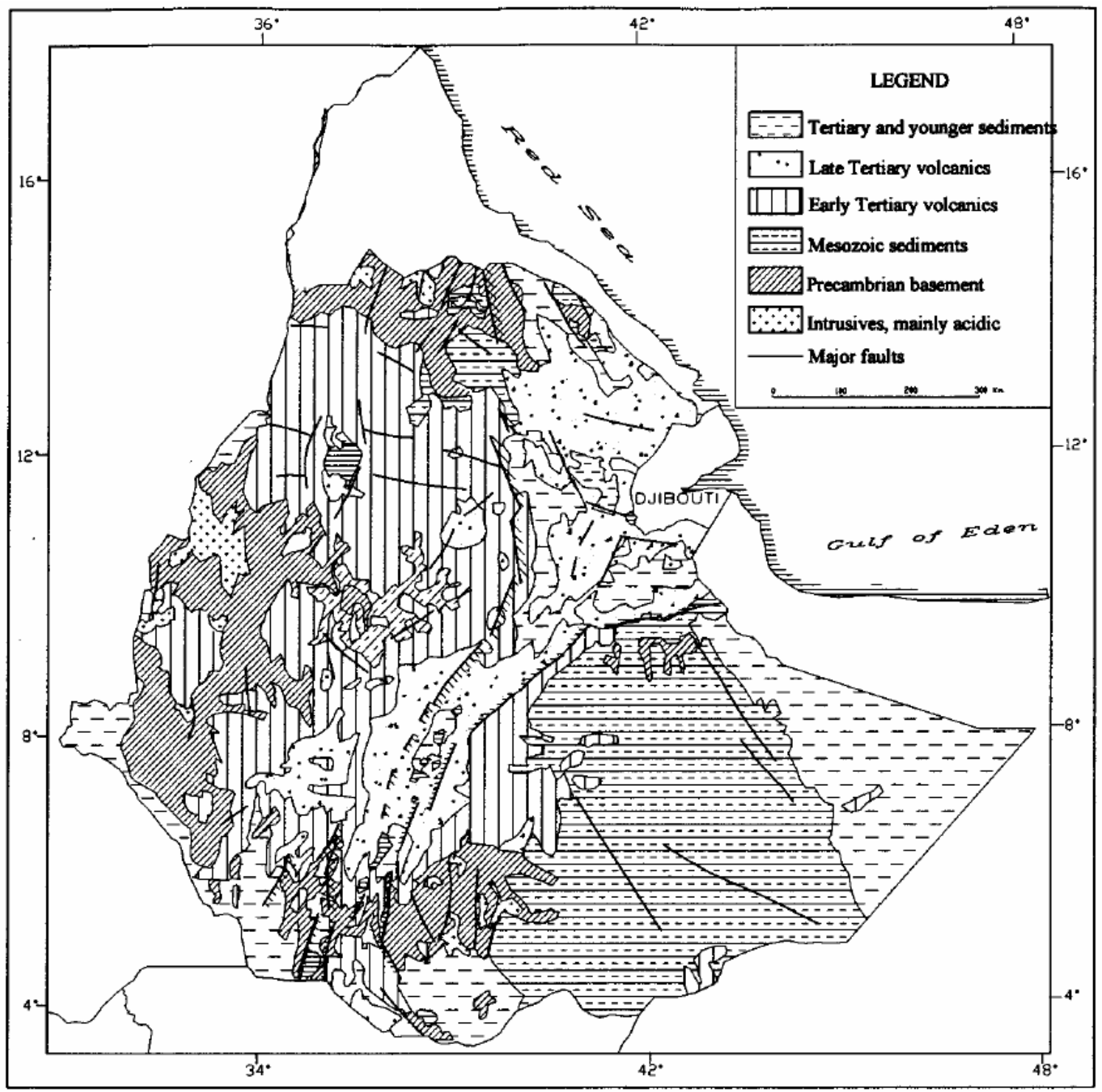

Fig. 2. Simplified Geological map of Ethiopia [modified from Mohr, 1970].

After the formation of the escarpments fissural volcanism was confined to the rifts. This new volcanic stage began with the emission of the Mabla rhyolitic ignimbrites and the voluminous Fursa flood basalts. The later occur at the base of the western plateau covering wide area. Later basic lavas largely prevailed in Afar and silicic products in the Main Ethiopian Rift (MER). They form the Dalha Basalts, the Afar Stratoid Series (4-1 Ma) and the younger volcanoes built on the axial fissure systems of the Afar (Barberi et al., 1975). Huge volumes of ignimbrites (Balchi Formation) locally interlayered with basalts, were emitted in the MER and in southern Afar. Younger basalts and peralkaline silicics of the Wonji Group built up volcanic edifices in the axial zone of the MER, mostly in the lakes region (Kazmin et al., 1980). The youngest volcanics are associated with obsidian flows, ignimbrite, pumice deposits with rhyolitic flows and domes, pyroclastic surge deposits, basaltic lava flows and spatter cones. They mostly outcrop in the rift, with the exception of the Quaternary basalts of the Lake Tana basin in north-western highlands.

The Plio-Quaternary sediments are alluvial, lacustrine, elluvial and colluvial deposits. Alluvial plains have filled up grabens and large stretches of flat land in the rift valley and along the whole length of the western boarder of the country (Tesfaye Chernet, 1993). The alluvial deposits filled troughs in the lowlands during the pluvial period and streams deposited large amounts of sediments carried down from the highlands. Thin strips of alluvium along rivers occur in most places both in 
the highlands and the lowlands. In the Afar depression there are thick alluvial, lacustrine and marine sediments. These sediments are associated with thick evaporites including gypsum, anhydrite, common salt and in places conglomerates, sand, clay, reef limestone and marl. The lacustrine deposits are of purely lake or swamp and volcano-lacustrine deposits. Extensive lacustrine sediments are located around existing large lakes. Elluvials occur extensively within the metamorphic terrain in southern Ethiopia and in the basement rocks of north-western Ethiopia. The eluvial lateritic crust consists of clay, silt and fine sand; but it has dominantly silt and fine sand. Sheet flood deposits occur in the Danakil Depression. Sand dunes of small sizes are known in the Afar region. Small alluvial fans associated with colluvial deposits occur almost everywhere at the feet of mountainous areas and fault scarps. Thick evaporite deposits characterize the Afar region.

The studied regions are affected by different generations of tectonism. The rift valley and adjacent escarpments are extremely faulted. The fault systems in these regions are parallel and subparallel to the axis of the rift, dominantly NE-SW (Giday Woldegebriel et al., 1990). There are at least three sets of faults in the Afar associated with the triple junction representing the Ethiopian Rift, Red Sea and the Gulf of Aden. In the highlands there are different fault systems characterizing older rift systems and structural trends in the Precambrian rocks.

\section{SAMPLING AND ANALYTICAL METHODS}

A total of 237 new samples were collected within the studied area by the author since 1993. Raw data from previous works were also used to cover wider area (Baxter et al., 1965; Talling and Talling, 1965; UNDP, 1973; Wood and Talling, 1988; Panichi, 1995). The total number of samples used for the analysis is 452 .

Geographically the sampling areas are categorized into three broad physiographic and climatic zones: rift floor (R), escarpment (E) and highland $(\mathrm{H})$. The rift valley in turn is divided into the MER (R-1) and the Afar (R-2) with considerations of lithological associations, topography and climate. Afar is characterized by extreme aridity and existence of tectonic depressions filled with thick evaportie deposits, which have important influence on hydrochemistry. The escarpments located between the rift floor and the highlands are separated as western (E-1) and eastern (E-2). They have transitional climatic conditions with intermediate groundwater residence time situated between the regional highland groundwater recharge zones and rift discharge areas. The highlands are separated as western $(\mathrm{H}$ 1 ) and eastern (H-2). The former is further divided in to the highlands in Tigray (H1-B) and the rest of the broad western plateau (H1-A). The highlands in Tigray are distinguished from the rest of the western highlands (H1-A) owing to the occurrence of thick Mesozoic sedimentary rocks affecting the hydrochemistry significantly. The most important sampling localities in each zone are the following:

Western highlands (H-1A): Hosana, Jimma, Agaro, Gore, Nekemte, Debre Berhan, Debre Markos, Bahir Dar, Gonder, Debre Tabor, Nefas Mewcha, Dessie and Kombolcha.

Highlands in Tigray (H1-B): Mekele, Wukro, Axum, Adigrat, Maichew, Abi Adi and Adwa.

Eastern highlands (H-2): Assela, Bekoji, Koffele, Melka Wakena, Goba, Robe, Gasera, Ginir, Bore and Agere Selam.

Western escarpment (E-1): Butajira, Silte, Wulbareg, Addis Ababa, Akaki, Shewa Robit, and Bati.

Eastern escarpment (E-2): Diredawa, Harar, Asebe Teferi, Asebot, Wondo, Dilla and Yirga Chefe.

The MER (R-1): It includes what is commonly known as the lakes district including the upper Awash basin. The main sampling urban centres are Arba Minch, Awassa, Shashemene, Arsi Negele, Ziway, Meki, Mojo, Debre Zeit, Nazreath, Wonji, Awash Arba, Metehara. The samples include a wide range of lake and thermal waters.

Afar: Mile, Asaita, Logia, Dubti, Serdo, Elidar and Afdera area.

The total samples analyzed from the rift floor, escarpments and highlands are 129, 125 and 198 respectively. The samples were analysed at different times at the Central Laboratory of the Ethiopian Geological Survey, and the laboratory of SABA Engineering private company and Aquatar Enterprise of Warsaw (Poland).

Samples were collected carefully and kept in polyethylene sample bottles and completely filled 
and tightened with double-sealed plastic caps. TDS and $\mathrm{pH}$ was measured in situ using TDS kit and $\mathrm{pH}$ meter respectively. For some samples the TDS in $\mathrm{mg} / \mathrm{l}$ is obtained by multiplying the EC (expressed in $\mu \mathrm{S} / \mathrm{cm}$ ) with a factor of 0.75 . Samples from wells were collected using a Klyen downhole and stainless steel borehole sampler. New polyvinyl chloride syringes were used to collect spring samples. Water samples from hot springs were collected from the hottest points directly above the emanation points. In rivers, samples were collected at the centre of rivers and close to the surface during non-rainy periods. For lakes and swamps, samples were collected some 2 to 5 meters away from the shoreline at the surface. Care was taken to avoid contamination during and after sampling from anthropogenic influences such as washing, animals, inclusion of suspended solids, etc.

The laboratory analysis for the majority of the samples was made within twenty or less days of sampling. The hydrochemical analysis was conducted in the different laboratories of Ethiopia and Aquatar Enterprise in Warsaw (Poland). Many of the ions were analysed by ion selective electrode and Atomic Absorption Spectrophotometer. Sampling and analytical methods adapted for the water samples analysed in Ethiopia are described in UNDP (1973). As the samples were analysed in different laboratories and collected from various sources the analytical errors are variable. For the majority of the samples collected and analysed by the author the analytical error is less than 5\%. Certainly there is limitation in data quality from literature works (UNDP, 1973; Elizabeth Kebede et al., 1996); none of the data sources indicate the accuracy and analytical errors. However, for such a regional work the analytical procedures and results are of acceptable quality.

\section{RESULTS AND DISCUSSION}

\section{Water type classification}

Table 1 shows the selected representative data of the major ion chemistry, TDS and $\mathrm{pH}$ of the analysed samples in the three physiographic regions. On the basis of the concentration of major cations and anions, the waters were classified using Piper Trillinear diagram (Fig. 3). The result indicates that major cations and anions show strong variations water types reflecting the existence of different hydrogeological regimes. The dominant cations are $\mathrm{Ca}$ and $\mathrm{Mg}$ in the highlands and $\mathrm{Na}$ in the rift, and the dominant anions are $\mathrm{HCO}_{3}$ followed by $\mathrm{Cl}$ and $\mathrm{SO}_{4}$. The great majority of the groundwater and surface water systems are $\mathrm{Ca}-\mathrm{Mg}$ and Na bicarbonate type.

Table 1. Average ionic composition of different water bodies (mg/l).

\begin{tabular}{|c|c|c|c|c|c|c|c|c|c|c|c|c|c|c|c|c|c|c|}
\hline Location & Тур & $\begin{array}{l}\text { No. } \\
\text { e samples }\end{array}$ & Statistics & $\mathrm{Na}$ & $\mathrm{Ca}$ & $\mathrm{Mg}$ & $\mathbf{K}$ & $\mathrm{HCO}_{3}$ & $\mathrm{Cl}$ & $\mathrm{CO}_{3}$ & $\mathrm{SO}_{4}$ & $\mathbf{F}$ & $\mathrm{NO}_{3}$ & $\mathrm{SiO}_{2}$ & $\mathrm{HBO}_{2}$ & $\mathrm{CO}_{2}$ & TDS & $\mathrm{pH}$ \\
\hline \multirow{16}{*}{$\begin{array}{l}\text { Western } \\
\text { Highlands }\end{array}$} & \multirow[t]{3}{*}{ DW } & \multirow[t]{3}{*}{13} & minimum & 4.0 & 15.0 & 5.0 & 2.0 & 57.0 & 4.0 & 0.0 & 0.0 & 0.0 & 0.0 & 0.0 & 0.0 & 0.0 & 155.2 & 6 \\
\hline & & & maximum & 56.0 & 120.0 & 27.0 & 75.0 & 544.0 & 87.0 & 112.0 & 63.0 & 204.0 & 204.0 & 94.0 & 42.0 & 49.0 & 803 & 7.8 \\
\hline & & & median & 10.0 & 49.0 & 10.0 & 5.0 & 160.0 & 20.5 & 9.5 & 9.0 & 47.0 & 47.0 & 40.0 & 1.4 & 12.0 & 365.7 & 6.99 \\
\hline & \multirow[t]{3}{*}{$\mathrm{BH}$} & \multirow[t]{3}{*}{35} & minimum & 2.0 & 1.4 & 0.2 & 0.0 & 42.0 & 0.0 & 0.0 & 0.0 & 0.0 & 0.0 & 0.0 & 0.0 & 0.0 & 0 & 0 \\
\hline & & & maximum & 390.0 & 80.0 & 31.1 & 26.0 & 1178.0 & 48.0 & 42.5 & 31.0 & 89.0 & 89.0 & 97.0 & 60.0 & 24.0 & 1674.7 & 8.3 \\
\hline & & & median & 40.8 & 27.0 & 11.0 & 3.0 & 250.0 & 1.9 & 4.0 & 0.0 & 0.4 & 0.4 & 47.0 & 0.0 & 0.0 & 393.4 & 7.7 \\
\hline & \multirow[t]{3}{*}{ TS } & \multirow[t]{3}{*}{3} & minimum & 4.0 & 8.0 & 2.0 & 3.0 & 45.0 & 0.7 & 2.0 & & 1.5 & 1.5 & 30.0 & 0.4 & 8.0 & 124 & 6.86 \\
\hline & & & maximum & 6.0 & 37.0 & 7.0 & 6.0 & 166.0 & 5.0 & 6.0 & & 5.0 & 5.0 & 64.0 & 2.0 & 22.0 & 264 & 7.7 \\
\hline & & & median & 5.0 & 9.0 & 3.0 & 3.0 & 61.0 & 2.0 & 5.0 & & 4.0 & 4.0 & 39.0 & 1.2 & 13.0 & 143.2 & 7.28 \\
\hline & \multirow[t]{3}{*}{ CS } & \multirow[t]{6}{*}{4} & minimum & 153.0 & 4.8 & 1.5 & 12.0 & 698.0 & 25.9 & 0.0 & 1.0 & & & 0.0 & & & 960 & 6.5 \\
\hline & & & maximum & 280.0 & 78.6 & 52.5 & 48.1 & 1173.0 & 30.0 & & 9.0 & & & 157.0 & & & 960 & 8.2 \\
\hline & & & median & 180.0 & 6.0 & 4.0 & 38.7 & 935.5 & 28.4 & & 5.0 & & & 78.0 & & & 960 & 7.35 \\
\hline & \multirow[t]{3}{*}{$\mathrm{R}$} & & minimum & 9.0 & 24.0 & 7.0 & 2.0 & 145.0 & 5.0 & 0.0 & 5.0 & & & 9.0 & 4.1 & 7.0 & 231.3 & 6 \\
\hline & & & maximum & 18.0 & 30.0 & 11.0 & 3.0 & 150.0 & 9.0 & 18.0 & 5.0 & & & 21.0 & 4.1 & 9.0 & 249.5 & 7 \\
\hline & & & median & 12.0 & 26.0 & 8.0 & 2.0 & 150.0 & 6.0 & 0.0 & 5.0 & & & 20.0 & 4.1 & 8.0 & 232.4 & 6.5 \\
\hline & $\mathrm{L}$ & 1 & Actual & 5.5 & 18.9 & 5.5 & 1.6 & 92.7 & 1.6 & & 2.5 & & & 14.5 & & & & 8.4 \\
\hline \multirow{13}{*}{$\begin{array}{l}\text { Highlands } \\
\text { in Tigray }\end{array}$} & \multirow[t]{2}{*}{ DW } & \multirow[t]{3}{*}{6} & minimum & 7.8 & 56.0 & 28.0 & 0.5 & 48.0 & 1.5 & & 20.3 & 0.2 & 0.3 & 11.5 & 1.3 & 98.0 & 102 & 7.06 \\
\hline & & & maximum & 320.0 & 630.0 & 538.0 & 5.7 & 504.0 & 355.0 & & 1835.0 & 2.0 & 363.3 & 56.0 & 3.7 & 140.0 & 4670.3 & 7.86 \\
\hline & \multirow{4}{*}{$\mathrm{BH}$} & & median & 44.4 & 245.0 & 96.0 & 1.6 & 384.5 & 15.0 & & 82.7 & 0.4 & 3.6 & 23.7 & 2.3 & 118.0 & 509.5 & 7.31 \\
\hline & & \multirow[t]{3}{*}{18} & minimum & 14.0 & 110.0 & 7.3 & 1.0 & 167.0 & 12.0 & & 17.0 & 0.2 & 1.3 & 13.0 & 1.4 & 29.0 & 482.25 & 6.99 \\
\hline & & & maximum & 830.0 & 560.0 & 90.0 & 8.1 & 421.0 & 163.0 & & 2267.0 & 1.6 & 44.3 & 63.0 & 21.5 & 252.0 & 4438.5 & 7.69 \\
\hline & & & median & 30.5 & 202.0 & 25.5 & 2.5 & 287.5 & 21.0 & & 349.5 & 0.4 & 20.6 & 36.0 & 2.8 & 90.0 & 874.5 & 7.24 \\
\hline & \multirow[t]{3}{*}{ CS } & \multirow[t]{3}{*}{8} & minimum & 11.5 & 172.0 & 0.1 & 0.9 & 228.0 & 26.0 & & 38.6 & 0.3 & 12.5 & 18.7 & 0.9 & 77.0 & 401 & 7.01 \\
\hline & & & maximum & 60.0 & 285.0 & 88.0 & 3.1 & 437.0 & 43.7 & & 515.0 & 0.5 & 44.4 & 50.0 & 2.7 & 83.0 & 1490.3 & 7.37 \\
\hline & & & median & 25.5 & 218.0 & 25.0 & 2.2 & 341.5 & 29.0 & & 149.7 & 0.5 & 34.3 & 48.0 & 1.8 & 80.0 & 731.63 & 7.29 \\
\hline & \multirow[t]{3}{*}{$\mathrm{R}$} & \multirow[t]{3}{*}{4} & minimum & 1.1 & 12.4 & 0.3 & 1.0 & 33.0 & 3.0 & & 4.0 & 0.1 & 48.5 & 1.0 & 0.0 & 4.0 & 58.5 & 7.72 \\
\hline & & & maximum & 49.2 & 198.4 & 88.0 & 4.2 & 236.0 & 48.5 & & 448.4 & 2.0 & 48.5 & 27.5 & 0.0 & 4.0 & 865.5 & 8 \\
\hline & & & median & 40.0 & 178.0 & 21.9 & 2.7 & 190.3 & 24.0 & & 35.4 & 0.3 & 48.5 & 14.3 & 0.0 & 4.0 & 336 & 7.86 \\
\hline & PD & 1 & actual & & 148 & 94 & 195 & 184 & 12.5 & & 46.8 & 0.35 & 0.9 & 9 & & & 287 & 7.48 \\
\hline
\end{tabular}


Table 1. (Contd).

\begin{tabular}{|c|c|c|c|c|c|c|c|c|c|c|c|c|c|c|c|c|c|c|}
\hline Location & Type & $\begin{array}{l}\text { No. } \\
\text { samples }\end{array}$ & Statistics & $\mathrm{Na}$ & $\mathrm{Ca}$ & $\mathrm{Mg}$ & $\mathbf{K}$ & $\mathrm{HCO}_{3}$ & $\mathrm{Cl}$ & $\mathrm{CO}_{3}$ & $\mathrm{SO}_{4}$ & $\mathbf{F}$ & $\mathrm{NO}_{3}$ & $\mathrm{SiO}_{2}$ & $\mathrm{HBO}_{2}$ & $\mathrm{CO}_{2}$ & TDS & $\mathrm{pH}$ \\
\hline \multirow{11}{*}{$\begin{array}{l}\text { Eastern } \\
\text { Highlands }\end{array}$} & \multirow[t]{3}{*}{ DW } & \multirow[t]{3}{*}{9} & minimum & 2.5 & 6.4 & 2.2 & 1.0 & 34.0 & 2.5 & & 0.0 & 0.0 & 0.0 & 0.0 & 0.0 & 0.0 & 82 & 0 \\
\hline & & & maximum & 456.0 & 43.0 & 8.0 & 20.0 & 996.0 & 129.0 & & 74.0 & 2.1 & 0.0 & 98.0 & 2.2 & 4.0 & 1806 & 8 \\
\hline & & & median & 10.0 & 10.0 & 4.0 & 20.0 & 62.0 & 16.0 & & 7.0 & 0.1 & 0.0 & 33.0 & 1.2 & 2.0 & 164 & 7.55 \\
\hline & \multirow[t]{3}{*}{$\mathrm{BH}$} & \multirow[t]{3}{*}{18} & minimum & 10.8 & 16.2 & 2.0 & 0.0 & 79.3 & 0.0 & 0.0 & 0.0 & 0.0 & 0.0 & 36.8 & 0.0 & 0.0 & 8.1 & 6.4 \\
\hline & & & maximum & 312.0 & 72.1 & 28.2 & 20.0 & 1012.6 & 28.6 & 425.4 & 24.0 & 64.0 & 9.3 & 175.0 & 0.4 & 230.0 & 2072.9 & 8.8 \\
\hline & & & median & 36.6 & 46.3 & 11.2 & 5.8 & 268.2 & 5.5 & 14.2 & 0.0 & 0.5 & 1.2 & 63.0 & 0.0 & 0.0 & 480.45 & 7.45 \\
\hline & TS & 1 & actual & 55.0 & 16.0 & 3.0 & 8.0 & 228.0 & 6.0 & 0.0 & 1.0 & 1.8 & 0.0 & 105.0 & 1.0 & 7.0 & 423.0 & 7.7 \\
\hline & \multirow[t]{3}{*}{ CS } & \multirow[t]{3}{*}{7} & minimum & 5.0 & 3.0 & 1.0 & 0.9 & 31.0 & 0.4 & 0.0 & 0.0 & 0.1 & 0.0 & 8.0 & 0.2 & 3.0 & 102 & 0 \\
\hline & & & maximum & 30.0 & 36.0 & 23.0 & 6.0 & 256.0 & 6.0 & 15.0 & 6.0 & 0.4 & 13.3 & 81.0 & 2.3 & 32.0 & 457 & 8.14 \\
\hline & & & median & 12.0 & 18.0 & 5.5 & 2.5 & 105.5 & 2.5 & 4.4 & 0.0 & 0.3 & 5.1 & 44.5 & 0.2 & 7.0 & 220.5 & 7.08 \\
\hline & $\mathrm{L}$ & 1 & actual & 0.2 & 6.0 & 1.3 & 1.1 & 18.3 & 3.0 & & 7.7 & & & & & & & 6.4 \\
\hline \multirow{12}{*}{$\begin{array}{l}\text { Western } \\
\text { Escarpment }\end{array}$} & \multirow{3}{*}{ DW } & 6 & minimum & 11.0 & 11.0 & 6.0 & 1.8 & 182.0 & 4.0 & & 1.0 & 0.1 & 0.0 & 59.0 & 0.1 & 5.0 & 366 & 0 \\
\hline & & & maximum & 150.0 & 93.0 & 21.0 & 23.0 & 628.0 & 23.0 & & 25.0 & 4.1 & 88.0 & 106.0 & 2.0 & 14.0 & 987 & 7.4 \\
\hline & & & median & 38.0 & 58.0 & 18.0 & 14.0 & 366.0 & 9.0 & & 9.0 & 0.6 & 0.0 & 82.0 & 1.0 & 13.0 & 514 & 7 \\
\hline & $\mathrm{BH}$ & 84 & minimum & 0.1 & 0.8 & 0.2 & 0.0 & 26.0 & 0.1 & 0.0 & 0.0 & 0.0 & 0.0 & 0.0 & 0.0 & 0.0 & 50 & 0 \\
\hline & & & maximum & 864.0 & 228.0 & 71.1 & 64.8 & 2000.0 & 104.0 & 144.0 & 156.0 & 29.3 & 209.0 & 209.0 & 49.0 & 12.0 & 2436 & 8.3 \\
\hline & & & median & 30.0 & 51.0 & 12.0 & 2.0 & 211.0 & 26.6 & 0.0 & 14.5 & 0.5 & 4.9 & 42.7 & 0.0 & 0.0 & 393 & 7.3 \\
\hline & TS & 1 & actual & 1182.0 & 4.0 & nil & 60.0 & 2440.0 & 71.0 & & 54.0 & & & 60.0 & & & & \\
\hline & CS & 15 & minimum & 1.5 & 8 & 1.92 & 1 & 44 & 1 & & 1 & 0 & & 21 & 1 & 2 & 102 & 0 \\
\hline & & & maximum & 75.0 & 60.0 & 25.0 & 12.0 & 343.0 & 20.0 & & 26.0 & 8.9 & 4.4 & 87.0 & 22.0 & 9.0 & 539.4 & 8 \\
\hline & & & median & 14.0 & 30.0 & 8.0 & 4.5 & 138.0 & 3.5 & & 5.0 & 0.4 & 0.2 & 54.5 & 2.0 & 5.0 & 265 & 6.45 \\
\hline & $\mathrm{L}$ & 2 & minimum & 0.0 & 4.0 & 0.0 & 12.0 & 160.0 & 0.0 & & 8.0 & 0.6 & 0.0 & 0.0 & 0.0 & 0.0 & 336.6 & 7 \\
\hline & & & maximum & 180.0 & 30.0 & 7.3 & 22.0 & 490.0 & 36.0 & 57.0 & 22.0 & 140.0 & 0.0 & 11.0 & 2.5 & 0.0 & 901 & 8.6 \\
\hline Eastern & DW & 2 & minimum & 45.0 & 120.0 & 48.0 & 0.0 & 427.0 & 72.0 & 110.0 & & 0.6 & 0.0 & 4.1 & 0.0 & 0.0 & 980 & 7 \\
\hline Escarpment & & & maximum & 52.0 & 365.5 & 98.3 & 0.0 & 470.0 & 880.0 & 294.0 & & 0.6 & 49.0 & 45.0 & 0.0 & 0.0 & 2120 & 7.7 \\
\hline & $\mathrm{BH}$ & 12 & minimum & 12.0 & 7.0 & 2.0 & 0.0 & 73.0 & 0.0 & 0.0 & & 0.0 & 0.0 & 1.0 & 0.0 & 0.0 & 203 & 0 \\
\hline & & & maximum & 61.4 & 144.0 & 37.0 & 7.0 & 459.0 & 124.0 & 73.0 & 55.5 & 40.0 & 160.0 & 83.0 & 42.0 & 42.0 & 908.5 & 8.08 \\
\hline & & & median & 40.0 & 122.5 & 8.0 & 0.0 & 333.6 & 42.0 & 70.0 & 0.0 & 0.5 & 20.0 & 34.6 & 1.3 & 11.0 & 740.3 & 0 \\
\hline & TS & 1 & actual & 17.0 & 4.0 & 29.1 & 14.0 & 399.0 & 99.0 & 134.0 & 14.0 & 2.0 & 0.0 & 56.0 & 3.9 & 0.0 & 1020.0 & 8.2 \\
\hline & CS & 2 & minimum & 11.0 & 48.0 & 18.0 & 0.0 & 261.0 & 5.0 & 9.0 & 0.0 & 0.2 & 2.0 & 17.0 & 0.0 & 0.0 & 415 & 7.8 \\
\hline & & & maximum & 15.0 & 90.0 & 25.0 & 0.0 & 354.0 & 18.0 & 23.0 & 0.0 & 0.3 & 13.0 & 32.0 & 0.0 & 0.0 & 562 & 8.2 \\
\hline Main & DW & 30 & minimum & 19.0 & 2.0 & 1.0 & 6.0 & 100.0 & 3.0 & 0.0 & 1.0 & 0.8 & 0.0 & 56.0 & 0.1 & 0.0 & 259 & 0 \\
\hline Ethiopian & & & maximum & 780.0 & 47.0 & 42.0 & 23.0 & 1460.0 & 160.0 & 36.0 & 220.0 & 37.0 & 81.0 & 101.0 & 4.1 & 10.0 & 2800 & 8.9 \\
\hline Rift & & & median & 145.0 & 21.0 & 5.0 & 16.0 & 400.0 & 36.0 & 0.0 & 23.5 & 4.8 & 0.0 & 86.0 & 1.3 & 5.5 & 878 & 7.4 \\
\hline & $\mathrm{BH}$ & 68 & minimum & 1.0 & 0.0 & 0.5 & 0.0 & 9.8 & 2.0 & 0.0 & 0.0 & 0.0 & 0.0 & 9.0 & 0.0 & 0.0 & 129.5 & 0 \\
\hline & & & maximum & 575.0 & 100.0 & 48.0 & 41.0 & 2708.0 & 959.0 & 480.0 & 204.0 & 64.0 & 352.0 & 150.0 & 18.0 & 28.0 & 6383 & 9.2 \\
\hline & & & median & 19.0 & 14.0 & 5.0 & 15.0 & 610.0 & 14.2 & 0.0 & 0.0 & 0.5 & 0.0 & 90.0 & 0.0 & 0.0 & 653 & 0 \\
\hline & TS & 34 & minimum & 10.0 & 1.0 & 0.1 & 0.6 & 0.0 & 10.0 & 0.0 & 0.6 & 0.4 & 0.0 & 0.0 & 0.0 & 0.0 & 0 & 7.1 \\
\hline & & & maximum & 2325.0 & 72.0 & 181.0 & 80.0 & 2964.0 & 1612.0 & 264.0 & 394.0 & 78.0 & 12.0 & 163.0 & 26.0 & 59.0 & 7443 & 8.8 \\
\hline & & & median & 540.0 & 13.0 & 3.8 & 33.0 & 802.5 & 128.0 & & 91.0 & 7.5 & 0.4 & 117.0 & 2.4 & 23.0 & 1649 & 8.3 \\
\hline & CS & 15 & minimum & 11.0 & 1.0 & 1.0 & 1.1 & 4.9 & 0.0 & 0.0 & 0.0 & 0.0 & 0.0 & 28.5 & 0.0 & 0.0 & 104 & 0 \\
\hline & & & maximum & 205.0 & 31.0 & 13.0 & 13.6 & 505.0 & 35.0 & 0.0 & 46.0 & 9.8 & 13.2 & 120.0 & 2.1 & 6.0 & 415 & 8.3 \\
\hline & & & median & 22.0 & 13.0 & 5.4 & 4.7 & 142.5 & 5.0 & 0.0 & 4.5 & 0.5 & 1.7 & 69.5 & 1.0 & 4.0 & 158.5 & 7.3 \\
\hline & $\mathrm{R}$ & & minimum & 16.0 & 2.8 & 2.0 & 3.0 & 13.0 & 0.0 & 0.0 & 1.0 & 0.4 & 0.0 & 0.0 & 0.0 & 0.0 & 173 & 6.72 \\
\hline & & & maximum & 425.0 & 42.0 & 12.0 & 30.0 & 453.5 & 35.0 & 675.0 & 19.0 & 74.0 & 2.6 & 91.0 & 1.6 & 8.0 & 1394 & 8.8 \\
\hline & & & median & 44.0 & 11.6 & 5.0 & 9.2 & 174.0 & 8.0 & 0.0 & 4.3 & 3.7 & 0.0 & 12.0 & 0.1 & 3.0 & 325 & 7.64 \\
\hline & $\mathrm{L}$ & 9 & minimum & 19.0 & 1.0 & 0.5 & 5.0 & 181.0 & 5.0 & 0.0 & 0.0 & 0.8 & 0.0 & 6.0 & 0.0 & 0.0 & 26 & 7 \\
\hline & & & maximum & 13500.0 & 50.5 & 80.0 & 900.0 & 4758.0 & 5343.0 & 11460.0 & 593.0 & 200.0 & 20.0 & 295.0 & 59.0 & 6.0 & 36900 & 9.85 \\
\hline & & & median & 1320.0 & 5.0 & 2.0 & 42.0 & 1755.0 & 409.0 & 52.5 & 134.0 & 26.5 & 0.0 & 42.0 & 2.0 & 0.0 & 3606 & 9.17 \\
\hline Afar & DW & 8 & minimum & 35.0 & 32.3 & 10.0 & 0.0 & 134.0 & 1.6 & 11.0 & 0.0 & 0.3 & & 17.0 & 1.0 & 0.0 & 359 & 7.1 \\
\hline & & & maximum & 950.0 & 300.0 & 138.0 & & 390.0 & 3152.0 & 355.0 & 0.0 & 68.0 & & 86.0 & 27.0 & 35.0 & 4773 & 8 \\
\hline & & & median & 256.5 & 76.5 & 38.0 & & 290.0 & 208.5 & 151.0 & 0.0 & 1.2 & & 55.5 & 5.0 & 11.0 & 1217.5 & 7.38 \\
\hline & $\mathrm{BH}$ & 19 & minimum & 40.0 & 4.0 & 1.0 & & 240.0 & 57.0 & 31.0 & 0.0 & 0.3 & 0.0 & 11.3 & 0.0 & 0.0 & 0 & 0 \\
\hline & & & maximum & 559.6 & 232.0 & 68.0 & 12.0 & 585.6 & 445.0 & 432.5 & 12.0 & 5.6 & 511.0 & 86.0 & 24.0 & 13.0 & 1978 & 8.2 \\
\hline & & & median & 268.0 & 40.0 & 19.7 & 0.0 & 390.0 & 88.0 & 180.0 & 0.0 & 1.2 & 1.2 & 50.0 & 0.4 & 6.0 & 1155 & 7.6 \\
\hline & TS & 12 & minimum & 224.0 & 9.0 & 0.8 & 0.0 & 110.0 & 85.0 & 88.0 & 0.0 & 0.7 & 0.0 & 60.0 & 0.0 & 0.0 & 886 & 7.3 \\
\hline & & & maximum & 1198.0 & 278.0 & 61.0 & 17.0 & 1592.0 & 680.0 & 1974.0 & 17.0 & 6.0 & 0.6 & 346.0 & 9.0 & 123.0 & 3912 & 8.6 \\
\hline & & & median & 587.5 & 28.0 & 4.5 & 3.0 & 230.5 & 213.5 & 719.0 & 3.0 & 2.0 & 0.0 & 162.5 & 0.8 & 0.0 & 2431 & 7.95 \\
\hline & $\mathrm{L}$ & 3 & minimum & 140.0 & 38.3 & 11.1 & 0.0 & 88.0 & 55.3 & 86600.0 & 0.0 & 3.7 & & 35.0 & 96.0 & 4.0 & 145129 & 7.9 \\
\hline & & & maximum & 54942.5 & 21222.4 & 13967.9 & 11.0 & 64246.5 & 40730.2 & 86600.0 & 17002.9 & 3.7 & & 416.0 & 96.0 & 4.0 & 145129 & 10.3 \\
\hline & & & median & 37540.0 & 14640.0 & 1080.0 & 0.0 & 371.0 & 1326.0 & 86600.0 & 42.3 & 3.7 & & 66.0 & 96.0 & 4.0 & 145129 & 8 \\
\hline
\end{tabular}

Note : Open spaces indicate no record. If there is a single record the value for the minimum, maximum and median is the same. $\mathrm{DW}=$ hand dug well, $\mathrm{BH}=$ borehole, $\mathrm{TS}=$ thermal spring, $\mathrm{CS}=$ cold spring, $\mathrm{R}=$ river, $\mathrm{L}=$ lake, $\mathrm{PD}=$ pond. 


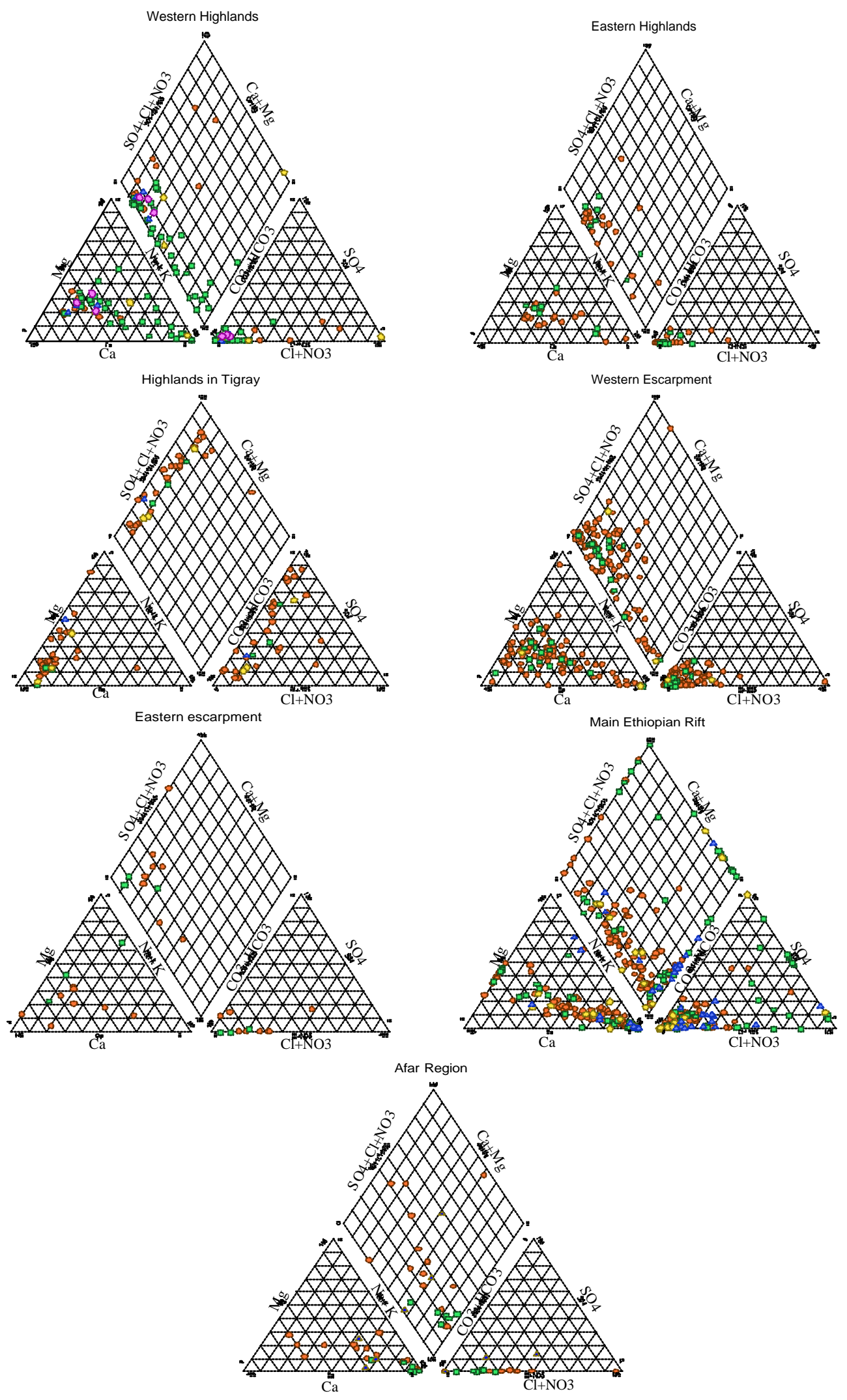

Note: circle=wells, square=springs, pentagon $=$ rivers, triangle $=$ lakes $\&$ dams

Fig. 3. Piper Trilinear diagrams (milliequivalent per liter). 
The Piper Trillinear diagram and scatter plots (Fig. 4) showing the relative proportions of the major cations, clearly demonstrate segregation of all the natural waters into three groups:

1.Soda springs, alkaline lakes and deep boreholes, which tend towards the $\mathrm{Na}+\mathrm{K}$ apex, with low calcium and magnesium. This is related mainly to reverse weathering process (Wood and Talling, 1988).

2. The groundwater and river waters with high $\mathrm{Ca}$ and $\mathrm{Mg}$ content localized in extensive elevated areas including highland lakes such as Ardibo and Hayq. Waters in this category have excellent to good chemical quality with $\mathrm{pH}$ mostly ranging from 7 to 8 and TDS mostly in the order of 1000 to $1500 \mathrm{mg} / \mathrm{l}$. In most sedimentary carbonate terrain these waters are hard.

3. Mixed waters in terms of major cations of $\mathrm{Na}$, $\mathrm{Ca}$ and $\mathrm{Mg}$ dominated by $\mathrm{HCO}_{3}$. The only exception is waters of eastern and central Tigray and some places of Afar with high $\mathrm{SO}_{4}$ content.
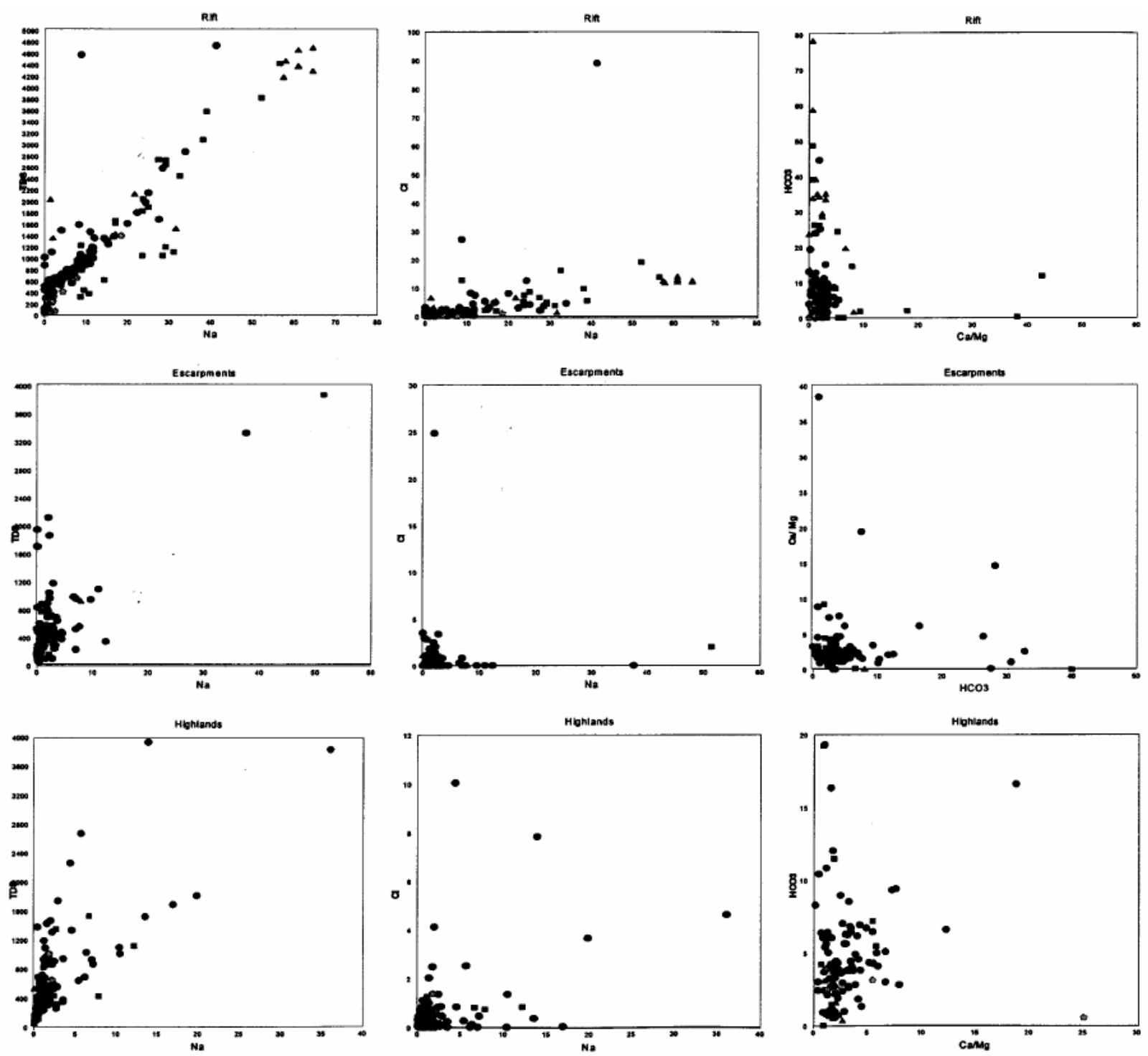

Fig. 4. Scatter plots of different ions and TDS (mg/l). (High TDS values represent alkaline terminal lakes and some geothermal wells and hot springs. High $\mathrm{Ca} / \mathrm{Mg}$ values indicate waters in basic volcanics and Mesozoic carbonates). 


\section{Relation of major ions and lithology}

Most of the waters within the basic and acidic volcanic province are dominated with $\mathrm{Ca}-\mathrm{Mg}$ and $\mathrm{Na}$ ions respectively. Calcium is an essential constituent of many igneous rock minerals, especially in the silicates of pyroxene, amphibole and the feldspar. In the volcanics the main sources of these ions come from the basic volcanics. In fact the carbonate rocks in the sedimentary sequences play important role in incised valleys and the highlands of Tigray giving peculiar hard $\mathrm{SO}_{4}$ dominated waters (Abdelwassie Hussien, 2000). Magnesium is typically a major constituent of the ferromagnesian minerals such as olivine, pyroxene and amphiboles, which form basic rocks. Sedimentary forms of magnesium include carbonates such as dolomite, magnesite and mixtures of magnesium with calcium carbonates. For example, the high $\mathrm{Mg}$ contents in central and south-western plateau result from preferential leaching of host basic rocks. A typical example of such process exists in the Hayq and Ardibo lakes and the upper Borkena river catchments (Mesfin Sahle, 2001; Molla Demellie, 2000), where highly weathered and altered basalts generate Mg-rich waters. Elemental proportions in the different water bodies of the rift floor show that $\mathrm{Na}(40-75 \%)$ is the dominant cation. The high concentration of $\mathrm{Na}$ in the rift waters is likely to be attributed to the dominance of the acidic volcanics, mainly ignimbrite, rhyolite and pumice.

In terms of anions the dominant one is $\mathrm{HCO}_{3}$. Almost all highland waters are dominated by this ion with the exception of waters in Tigray. In Afar evaporites play important role in generating $\mathrm{SO}_{4}$ and $\mathrm{Cl}$ ions. Often the principal source of $\mathrm{CO}_{2}$ that produce alkalinity and the $\mathrm{CO}_{3}$ and $\mathrm{HCO}_{3}$ ions in surface and groundwaters is the $\mathrm{CO}_{2}$ gas fraction of the atmosphere, or the atmospheric gases between the land surface and the water table. In some natural systems, there may be sources of $\mathrm{CO}_{2}$ other than dissolution of atmospheric or soil-zone $\mathrm{CO}_{2}$. Possible major local sources include biologically mediated sulphate reduction, metamorphism of carbonate rocks and in places out gassing from rocks in the mantle. Surface geochemical survey in the Ethiopian rift indicate that the high $\mathrm{HCO}_{3}$ is related to reaction of dissolved $\mathrm{CO}_{2}$ with rocks dominated by minerals with $\mathrm{Na}$, K-silicates common in acidic rocks. In the highlands much of the $\mathrm{CO}_{2}$ comes from the atmosphere and soil zone. However, the $\mathrm{CO}_{2}$ emanated from geothermal sources may play local role.

The high $\mathrm{HCO}_{3}$ content is also principally controlled by the silicate hydrolysis of the rock minerals and the incongruent reactions (Darling et al., 1996), which can be generalized as follows:

\section{Rocks $+\mathrm{H}_{2} \mathrm{CO}_{3}$ ? cations $+\mathrm{H}_{4} \mathrm{SiO}_{2}+\mathrm{HCO}_{3}+$ solids}

The geothermal waters in the MER are dominated by a single cation $(\mathrm{Na})$ and anion $\left(\mathrm{HCO}_{3}\right)$. Fournier and Truesdell (1970) suggested that in geothermal systems most of the $\mathrm{HCO}_{3}$ and part of the $\mathrm{Na}$ and $\mathrm{K}$ are produced by the reaction of dissolved $\mathrm{CO}_{2}$ with the rocks to produce mica or clay minerals and $\mathrm{HCO}_{3}$ ions. UNDP (1973) suggested a similar mechanism of the production of high $\mathrm{HCO}_{3}$ in the region:

$\mathrm{CO}_{2}+\mathrm{H}_{2} \mathrm{O}+\mathrm{Na}$,K-silicates ? $\mathrm{HCO}_{3}+\mathrm{Na}, \mathrm{K}+\mathrm{H}$-ilicates

At higher temperatures in geothermal systems, $\mathrm{K}$ is released from the rocks while $\mathrm{Na}$ is fixed with silicate minerals through a cation exchange reaction given by:

\section{K-silicates $+\mathrm{Na} \quad$ ～Na-silicates $+\mathrm{K}$}

According to Hem (1970), in acidic igneous rocks, $\mathrm{Na}$ is more abundant than $\mathrm{K}$. The major source of $\mathrm{Na}$ and $\mathrm{Cl}$ in the Afar are the evaporite deposits covering the volcanics. When $\mathrm{Na}$ has been brought into solution, it tends to remain in that status. There are no important precipitation reactions that can maintain low $\mathrm{Na}$ concentration in water, in the way that carbonate precipitation controls calcium concentrations. Sodium is also retained by adsorption on mineral surfaces, especially by minerals having high cationexchange capacities such as clays. Thus the water trapped in the sediment when it was laid down may be retained with its solute load for long periods. The $\mathrm{Na}$ of dilute waters in which dissolved solids concentrations are below 1000 $\mathrm{mg} / \mathrm{l}$ is generally in the form of $\mathrm{Na}$ ion. In more concentrated solutions (brine lakes), however, a 
variety of complex ions and ion pairs rich in $\mathrm{Na}$ may exist.

Considerably more important sources of $\mathrm{Cl}$ and $\mathrm{SO}_{4}$ are associated with sedimentary rocks, predominantly the evaporite as in the case of the Afar region. It may be present in resistates as the result of inclusion of connate brine and in cementing materials of Quaternary sediments and is to be expected in any incompletely leached deposits laid down in the sea or in a closed drainage basin. The typical example of this type is the high $\mathrm{Cl}$ in the crypto-depression of lakes Asal and Afdera (UNDP, 1973). Volcanic gases from geothermal fields may also introduce $\mathrm{Cl}$ in the groundwater systems and in some rift lakes. Some unusual high $\mathrm{Cl}$ in the Ziway-Shala basin is likely to be related to the influence of geothermal fields (Tenalem Ayenew, 1998).

In the Piper diagrams, more scattering is observed in cations than anions concentration. This is attributed either to mixing of different groundwater types and/or due to rock-water interactions and the climatic conditions related to the highland, escarpment and rift. Exceptional water samples rich in $\mathrm{Cl}$ are present in the MER. High $\mathrm{SO}_{4}$ waters in the MER are probably attributed to the effect of local lacustrine deposits associated with evaporates and the underlying sedimentary Mesozoic sequences in the north-eastern plateau in Tigray or in the northern edge of the MER close to the Afar depression.

Dramatic difference exists in $\mathrm{F}$ content between the highland and the rift waters. In nature F comes from chemical weathering products of igneous rocks, magmatic emissions, atmospheric dust from continental sources and industrial pollution (Hem, 1970). There is no agreement among researchers as to how the high $F$ is introduced into the groundwater and surface water bodies. According to Gerasimovskiy and Savinova (1969) the volcanic rocks of East Africa are richer in $\mathrm{F}$ than similar rocks in other parts of the world. This is supported by geochemical studies in the Ethiopian rift (Ashley and Burley, 1994; Peccerillo and Gezahegn Yirgu, 1996). The most important sources are acidic volcanic rocks such as tuff, pumice and obsidian and emanations from geothermal systems (Tesfaye Chernet, 1982; Tesfaye Chernet et al., 2001). The relative importance of geothermal systems and leaching of acidic rocks in introducing $\mathrm{F}$ in the rift waters is not well understood yet. This study also demonstrates the close association of high $\mathrm{F}$ waters to geothermal systems and acidic volcanics. According to Darling et al. (1996), the high F in saline lakes of the East African Rift reflects the nearly complete removal of $\mathrm{Ca}$ by carbonate precipitation usually as calcium carbonate.

All the major rift lakes are dominated by $\mathrm{Na}$. Ca and $\mathrm{Mg}$-dominated groundwater in the MER and southern Afar is often related to highland groundwaters flowing towards the rift through open fault systems and shallow alluvio-colluvial deposits; while $\mathrm{K}$ barely constitutes $10 \%$ of the cations in almost all waters. Bicarbonate constitutes the overwhelmingly dominant anion, ex cept in the central and northern Afar where different types of evaporites and associated Quaternary alluvial deposits cover the volcanic sequences giving rise to $\mathrm{Cl}$ and $\mathrm{SO}_{4}$ rich waters.

\section{Physiography and hydrochemistry}

Generally, there is a clear zonation in the total ionic concentration of natural waters following the direction of groundwater flow from the highlands to the rift valley, where the rainfall is low and the evaporation is very high. This zonation corresponds with the spatial variations of recharge and discharge conditions, climate and geological setting. The sharp increase in the total ionic concentration towards the rift implies that the residence time of groundwater and the magnitude of rock-water interaction are likely to increase in the same direction. However, there are local fresh waters in the rift valley controlled by the rift faults ultimately derived from fast circulating recharge from the high rainfall of the plateaux.

In view of the general similarity of rock types drained by streams and rivers in many highland volcanic terrains the major ion chemistry is not significantly variable. Almost all highland waters are $\mathrm{Ca}-\mathrm{Mg}$ bicarbonate type. All highland surface waters and groundwaters are fresh, characterized by low TDS often ranging from 50 to $1200 \mathrm{mg} / \mathrm{l}$. Some local exceptions with high TDS exist in the Akaki river catchments (Addis Ababa region) where the water is polluted by antheropogenic influences. High TDS occur also in the Mesozoic sedimentary rocks interbedded with thin beds of 
gypsum (Abdelwassie Hussien, 2000; Solomon Tale, 2000; Lemessa Mekonta, 2001). Some water samples from urban areas such as Addis Ababa, Nazreth, Wonji, Bahir Dar and rural irrigated fields have high $\mathrm{NO}_{3}$ content (Teshome Dechassa, 1999; Solomon Tale, 2000). Some of the waters from these areas are extremely polluted; for example a borehole in Asebot town (in southern Afar) has $\mathrm{NO}_{3}$ of $511 \mathrm{mg} / \mathrm{l}$.

The large contrast in the type and amount of ionic concentration between waters of the rift and the highlands indicates that the two systems have different hydrogeological regimes, in terms of lithology, groundwater residence time, precipitation-evaporation ratio and geothermal manifestations. The low TDS of highland waters signify that the groundwater in these regions consists of meteoric water originated from direct precipitation recharge circulating at shallow depths. The rift deep waters are related to slowly circulating groundwater attaining high ionic concentrations due to strong rock-water interactions and partly to the influence of geothermal systems and high evaporation rate with no or very low direct recharge. However, most of the shallow highland groundwater with low TDS reaches the rift by flowing through topsoil and weathered rock zones in the upper few tens of meters. This has been demonstrated using numerical groundwater flow modelling in the Ziway-Shala basin (Tenalem Ayenew, 2001). These waters provide sustained base flow to many rivers and shallow dug wells or flow through discrete rift faults; at times emerge as cold springs and wide seepage zones in the escarpment and rift valley. Typically such hydrogeological systems are present in the feet of the Gurghe Mountains and the escarpments adjoining the Arsi plains and many other places in the escarpment of the MER to the south.

Extensive isotopic studies in the highlands and the rift floor extending from Lake Abaya to Lake Ziway have revealed that much of the water in the Ethiopian highland volcanic terrain is related to very recent fast circulating meteoric water originated from wet season rainfall, except waters in few geothermal fields within the MER (Craig, 1977; Panichi, 1995; Berhanu Gizaw, 1996; Tenalem Ayenew, 1998). The TDS value is usually less than $300 \mathrm{mg} / \mathrm{l}$ above the altitude of 2500 meters.
Most of the springs in the highlands and transitional escarpments are cold with temperatures close to the ambient temperature. This is either due to lack of interaction with geothermal systems (unlike the rift hot springs) or to near surface mixing with meteoric water. The $\mathrm{pH}$ varies within a narrow range, but there is a wide range in alkalinity (10 to $1500 \mathrm{mg} / \mathrm{l}$ ), especially in the eastern escarpment of the central and northern MER. Some springs are less mineralised and also are acidic (at times $\mathrm{pH}$ as low as 6) and $\mathrm{CO}_{2}$ out gassing is virtually absent, suggesting that there is sufficient time or flow path (near surface conditions) for the $\mathrm{CO}_{2}$ rich fluid to react extensively with the surrounding rock following its dissolution in the groundwater and resulting in low $\mathrm{pH}$ waters (UNDP, 1973).

The thermal waters (hot springs, thermal wells and fumaroles) in the MER have very high TDS, with a particular composition of high $\mathrm{Na}$ and $\mathrm{HCO}_{3}$ contents and very low $\mathrm{Ca}$ and $\mathrm{Mg}$, which stand in contrast to waters from many of the boreholes and cold springs in the same region (Table 1). As evidenced from isotopic studies, the major geothermal systems of the rift are dominated by deep groundwater circulating with little or no dilution by substantial shallow meteoric water (Craig, 1977; Panichi, 1995; Tenalem Ayenew, 2003). The deep thermal waters contain a relatively low $\mathrm{Cl}$ compared to other volcanic areas, their $\mathrm{SO}_{4}$ concentration is similar to those found in other geothermal fields in the Afar (Ellis and Mahon, 1977). But, the thermal waters of the MER can be easily differentiated from the Afar, by their low $\mathrm{Cl}$.

Both hydrochemical and isotope data has revealed mixing of the thermal waters with shallow meteoric waters in the hot springs of Langano, Shala and Awassa areas (Tesfaye Chernet, 1982; Berhanu Gizaw, 1996; Tenalem Ayenew, 1998). These diluted high-discharge springs are controlled by large fault systems. The deep thermal water of the springs is mixed with the fresh highland waters that come through discrete fractures.

In contrast to the rift valley lakes, all highland lakes, including the large Lake Tana, are fresh and flushed by fast flowing shallow groundwater systems related to high precipitation and surface water inputs from rivers and overland flow. The 
total ionic concentration of the lakes is not very different from the feeder rivers and the groundwater systems of the surrounding highlands. Table 2 shows the major ion composition of some lakes, selected thermal waters, and regional representative deep and shallow groundwater from boreholes, hand-dug wells and cold springs.

Table 2. Major ionic composition of main lakes and selected water samples from representative sites (mg/l).

\begin{tabular}{|c|c|c|c|c|c|c|c|c|c|c|c|c|c|c|c|c|}
\hline \multicolumn{2}{|r|}{ No. Location/water bodies } & \multirow{2}{*}{$\begin{array}{l}\text { Source of data, year } \\
\text { Author, } 1996\end{array}$} & \multicolumn{2}{|c|}{ Type Na } & \multirow{2}{*}{$\begin{array}{l}\mathrm{Ca} \\
9.0\end{array}$} & \multirow{2}{*}{$\begin{array}{l}\mathrm{Mg} \\
3.9\end{array}$} & \multirow{2}{*}{$\begin{array}{l}\mathrm{K} \\
17.2\end{array}$} & \multirow{2}{*}{$\begin{array}{l}\mathrm{HCO} 3 \\
571.7\end{array}$} & \multirow{2}{*}{$\begin{array}{l}\mathrm{Cl} \\
39.3\end{array}$} & \multirow[t]{2}{*}{$\mathrm{CO}_{3}$} & \multirow{2}{*}{$\frac{\mathrm{SO}_{4}}{4.3}$} & $\mathrm{~F}$ & $\mathrm{NO}_{3}$ & $\mathrm{NO}_{2}$ & TDS & $\mathrm{pH}$ \\
\hline 1 & Abaya & & $\mathrm{L}$ & 209.9 & & & & & & & & & & & 574 & 8.8 \\
\hline 2 & Chamo & Author, 1996 & $\mathrm{~L}$ & 264.8 & 2.2 & 3.8 & 14.1 & 573.5 & 64.9 & & 4.1 & 1.8 & 1.9 & & 778 & 8.9 \\
\hline 3 & Awassa & Author, 1996 & $\mathrm{~L}$ & 225.0 & 7.0 & 5.5 & 39.0 & 384.0 & 34.0 & 90 & 2.0 & 9.0 & & & 904 & 9.5 \\
\hline 4 & Shallo & Author, 1996 & $S$ & 29.9 & 7.0 & 2.1 & 5.1 & & 7.1 & & 1.9 & 1.1 & & & 26 & 7.7 \\
\hline 5 & Chitu & Author, 1996 & $\mathrm{~L}$ & 13500.0 & 1.0 & 1.0 & 900.0 & 4758.0 & 5343.0 & 11460 & 386.0 & 200.0 & & & 36900 & 9.9 \\
\hline 6 & Shala & Author, 1996 & $\mathrm{~L}$ & 5600.0 & 1.0 & 1.0 & 200.0 & 3569.0 & 2663.0 & 3090 & 100.0 & 175.0 & & & 15500 & 9.6 \\
\hline 7 & Abiyata & Author, 1996 & $\mathrm{~L}$ & 4700.0 & 1.0 & 0.5 & 250.0 & 2367.0 & 2095.0 & 311 & 148.0 & 130.0 & & & 13480 & 9.6 \\
\hline 8 & Langano & Author, 1996 & $\mathrm{~L}$ & 390.0 & 4.5 & 2.0 & 26.0 & 586.0 & 182.0 & 96 & 44.0 & 13.0 & & & 1411 & 9.2 \\
\hline 9 & Ziway & Author, 1996 & $\mathrm{~L}$ & 70.0 & 17.0 & 8.4 & 13.1 & 146.0 & 13.0 & 80 & 13.0 & 1.9 & & & 277 & 8.5 \\
\hline 10 & Aba Samuel & Author, 1997 & $\mathrm{D}$ & & 30.0 & 7.3 & 12.0 & 160.0 & 36.0 & & 8.0 & 0.6 & & & 337 & 7.0 \\
\hline 11 & Wonchi & Lemessa Mekonta, 2001 & $\mathrm{~L}$ & 18.4 & 11.2 & 2.4 & 9.8 & 120.8 & 8.0 & & & 1.0 & 6.2 & & 106 & 8.2 \\
\hline 12 & Bishoftu & Seifu Kebede, 2000 & $\mathrm{~L}$ & 30.0 & 5.0 & 80.0 & 60.0 & 1430.0 & 220.0 & 150 & 21.0 & 1.1 & & & 2531 & 9.0 \\
\hline 13 & Hora & Seifu Kebede, 2000 & $\mathrm{~L}$ & 44.0 & 6.0 & 60.0 & 48.0 & 820.0 & 100.0 & 230 & 12.0 & 0.8 & & & 1602 & 9.0 \\
\hline 14 & Beseka & Elizabeth et al., 1996 & $\mathrm{~L}$ & 1480.0 & 6.0 & 2.0 & 42.0 & 2074.0 & 423.0 & & 593.0 & 33.0 & 17.0 & & 3652 & 9.1 \\
\hline 15 & Hayq & Author, 2001 & $\mathrm{~L}$ & 94.0 & 23.0 & 62.0 & 10.0 & 501.0 & 49.0 & 34 & 2.0 & 0.9 & 2.5 & & 680 & 8.8 \\
\hline 16 & Ardibo & Molla Demellie, 2000 & $\mathrm{~L}$ & 50.0 & 17.0 & 36.0 & 5.3 & 326.0 & 29.0 & 20 & 0.4 & 0.5 & 0.9 & & 432 & 8.6 \\
\hline 17 & Abhe & Gasse, 1980 & $\mathrm{~L}$ & 54943 & 21222 & 13968 & 0 & 64246 & 40730 & & 17002.9 & & & & 416 & 10.3 \\
\hline 18 & Gamari & UNDP, 1973 & $\mathrm{~L}$ & 140.0 & 38.3 & 11.1 & 10.9 & 369.1 & 55.3 & & 4.2 & & & & $>1000$ & 8.0 \\
\hline 19 & Afdera & UNDP, 1973 & $\mathrm{~L}$ & 37540.0 & 14640.0 & 1080.0 & & 88.0 & 1326.0 & 86600 & & 3.7 & & & 145129 & 7.9 \\
\hline 20 & Tana & Author, 1999 & $\mathrm{~L}$ & 5.5 & 18.9 & 5.5 & 1.6 & 92.7 & 1.6 & & 0.2 & & & & 103 & 8.4 \\
\hline 21 & Tarn1 & Lofeller, 1978 & $\mathrm{~L}$ & 0.2299 & 6.012 & 1.337 & 1.06 & 18.304 & 2.978 & & 7.7 & & & & & 6.2 \\
\hline 22 & Beseka & Author, 2002 & $\mathrm{~L}$ & 1960.0 & 1.3 & 17.0 & 67.6 & 3218 & 525.3 & & 525.8 & 31.4 & & 35.0 & 6921 & 9.4 \\
\hline 23 & Jewehariver & Author, 2002 & $\mathrm{R}$ & 77.87 & 26.46 & 14.04 & 4.72 & 331.8 & 34.5 & & 85.8 & 0.8 & & 10.8 & 587 & 8.8 \\
\hline 24 & Borkena & Author, 2002 & $\mathrm{R}$ & 37.0 & 60.4 & 24.8 & 2.3 & 421 & 16.1 & & 12.6 & & & 6.7 & 581 & 8.2 \\
\hline 25 & Gimba,Mersa & Author, 2002 & $\mathrm{R}$ & 19.7 & 66.4 & 29.6 & 1.5 & 390 & 13.7 & & 12.2 & & & 28.7 & 562 & 8.1 \\
\hline 26 & Awash at Asayita & Author, 2002 & $\mathrm{R}$ & 140.9 & 20.3 & 6.7 & 9.2 & 351 & 71.1 & & 48.8 & 2.4 & & 8.8 & 659 & 8.8 \\
\hline 27 & Awash at source & Author, 2002 & $\mathrm{R}$ & 17 & 48 & 16.6 & 4 & 268.4 & 6.2 & & 3.6 & & & 12.1 & 376 & 7.7 \\
\hline 28 & Awash at Wonji & Author, 2002 & $\mathrm{R}$ & 71 & 32.7 & 6.3 & 10.9 & 300 & 25.3 & & 15.3 & 2.5 & & 1.2 & 465 & 8.3 \\
\hline 29 & Termaber & Author, 2002 & CS & 5.2 & 13.4 & 2.4 & 1 & 60 & 1.3 & & 1.1 & 0.1 & & 5.8 & 90 & 6.9 \\
\hline 30 & Debre Sina & Author, 2002 & CS & 5.2 & 15 & 3.8 & 1 & 85.4 & 0.9 & & 0.9 & 0.1 & & 2.7 & 115 & 7.4 \\
\hline 31 & Tosa, Dessie & Author, 2002 & CS & 16.6 & 40.16 & 7.9 & 0.44 & 212.5 & 4.0 & & 4.4 & 0.2 & & 4.2 & 290 & 7.5 \\
\hline 32 & Yela, Harbou & Author, 2002 & CS & 20.81 & 83.95 & 29.7 & 0.76 & 414 & 17.0 & & 12.4 & & & 38.8 & 617 & 7.5 \\
\hline 33 & Chefa & Author, 2002 & CS & 75.18 & 16.88 & 10.68 & 1.15 & 230 & 10.3 & & 39.3 & 0.5 & & 8.6 & 393 & 8 \\
\hline 34 & Fontanina, Kombolcha & Author, 2002 & CS & 73.54 & 54.7 & 37.95 & 0.82 & 480 & 12.8 & & 15.9 & & & 29.3 & 705 & 7.5 \\
\hline 35 & Bako town & Author, 2002 & CS & 19 & 32 & 7.9 & 3 & 96 & 25.2 & & 4.2 & 0.2 & & 70.4 & 258 & 6.1 \\
\hline 36 & Sokoru & Author, 2002 & CS & 11.0 & 12.4 & 2.4 & 5.1 & 16 & 13.9 & & 3.2 & & & 43.8 & 108 & 6.1 \\
\hline 37 & Arjo town & Author, 2002 & CS & 11.6 & 8.8 & 3 & 11 & 6 & 21.9 & & 8.0 & 0.1 & & 35.3 & 106 & 7.9 \\
\hline 38 & Meteca & Author, 2002 & TS & 243.2 & 2.31 & 0.73 & 13.2 & 427 & 108.9 & & 93.2 & 1.9 & & 11.0 & 901 & 8.4 \\
\hline 39 & Addis Ababa Fliwuha & Author, 1996 & TS & 1182.0 & 4.0 & 1 & 60.0 & 2440.0 & 71.0 & & 54.0 & & & & & \\
\hline 40 & Ambo & Author, 1996 & TS & 153.0 & 78.6 & 52.5 & 38.7 & 1173.0 & 28.4 & & 1 & 1.0 & & & & 6.5 \\
\hline 41 & Sodere & Author, 1996 & TS & 670.0 & 12.0 & 7.0 & 33.0 & 1455.0 & 176.0 & & 140.0 & 7.4 & 12.0 & & 2656 & 7.6 \\
\hline 42 & Near Abaya swamp & Author, 1996 & TS & 225.0 & 8.0 & 2.0 & 23.0 & 600.0 & 22.0 & 0 & 2.0 & 5.2 & & & 1032 & 8.6 \\
\hline 43 & East of lake Shala & Author, 1996 & TS & 2325.0 & 1.0 & 1.0 & 37.0 & 2964.0 & 1612.0 & 264 & 40.0 & 78.0 & & & 7443 & 8.8 \\
\hline 44 & Southwest of lake Shala & Author, 1996 & TS & 1300.0 & 1.0 & 1.0 & 80.0 & 2379.0 & 486.0 & 0 & 64.0 & 29.0 & & & 3091 & 8.8 \\
\hline 45 & Oitu (Langano) & Author, 1996 & TS & 875.0 & 3.0 & 1.0 & 46.0 & 1586.0 & 342.0 & 0 & 19.0 & 51.0 & & & 3091 & 8.2 \\
\hline 46 & Edu geyser (Langano) & Author, 1996 & TS & 750.0 & 4.5 & 0.1 & 27.2 & 720.0 & 570.0 & & 360.0 & 16.5 & 3.4 & & & 8.8 \\
\hline 47 & Bricho (Aroresa) & Author, 1994 & TS & 575.0 & 1.0 & 1.0 & 21.0 & 445.0 & 305.0 & 0 & 394.0 & 12.0 & & & 1903 & 8.7 \\
\hline 48 & Negle Town & Author, 1996 & TS & 200.0 & 72.0 & 181.0 & 2.5 & 238.0 & 450.0 & & 82.0 & & & & 1255 & 8.1 \\
\hline 49 & Wondo Genet & Author, 1997 & TS & 655.0 & 23.0 & 7.0 & 67.0 & 1530.0 & 128.0 & & 166.0 & 2.0 & & & & 8.4 \\
\hline 50 & Wodo Genet & Author, 1997 & TS & 197.9 & 21.0 & 9.1 & 53.2 & & 40.4 & & 4.3 & & & & & \\
\hline 51 & Wolliso & Author, 1996 & TS & 280.0 & 4.8 & 1.5 & 12.0 & 698.0 & 30.0 & & 9.0 & 1.0 & & & & \\
\hline 52 & Shallo swamp & Author, 1994 & TS & 215.0 & 38.1 & 9.1 & 19.9 & & 60.2 & & 94.6 & & & & & 8.1 \\
\hline 53 & Herta Alle & UNDP, 1973 & TS & 224.0 & 9.0 & 5.0 & 10.0 & 339.0 & 85.0 & 111 & 10.0 & 2.0 & & & 886 & 7.9 \\
\hline 54 & Dere Dawa & UNDP, 1973 & TS & 17.0 & 4.0 & 29.1 & 14.0 & 399.0 & 99.0 & 134 & 14.0 & 2.0 & & & 1020 & 8.2 \\
\hline 55 & Afdera spring & UNDP, 1973 & TS & 895.0 & 278.0 & 61.0 & & 122.0 & 190.0 & 1974 & & 2.0 & & & 3655 & 8.0 \\
\hline 56 & Allallobed, Tendaho & UNDP, 1973 & TS & 545.0 & 25.0 & 0.8 & 17.0 & 119.0 & 260.0 & 710 & 17.0 & 0.7 & & & 2090 & 8.4 \\
\hline 57 & Gergedi thermal spring & Author, 2002 & TS & 207.2 & 2.59 & & 15.3 & 509 & 23.6 & & 27.4 & 14.4 & & 4.6 & 804 & \\
\hline 58 & Sodere & Author, 2002 & TS & 626.5 & 9.4 & 0.3 & 40.1 & 1200 & 154.8 & & 139.5 & 8.4 & & 7.9 & 2187 & 7.4 \\
\hline 59 & Woliso Ghion Hotel & Author, 2002 & TS & 262.3 & 1.6 & & 11.9 & 732 & 392 & & & 26.6 & & 2.3 & 1076 & 7.8 \\
\hline 60 & Adeso, Dedesa Valley & Author, 2002 & TS & 728.0 & 16.5 & 14.1 & 30.2 & 1650 & 36.7 & & 95.5 & 4.6 & & 37.6 & 2613 & 6.8 \\
\hline
\end{tabular}


Table 2. (Contd).

\begin{tabular}{|c|c|c|c|c|c|c|c|c|c|c|c|c|c|c|c|}
\hline No. Location/water bodies & \multirow{2}{*}{$\begin{array}{l}\text { Source of data, year } \\
\text { Author, } 2002\end{array}$} & \multicolumn{2}{|c|}{ Type Na } & \multirow{2}{*}{$\begin{array}{l}\mathrm{Ca} \\
45.65\end{array}$} & \multirow{2}{*}{$\begin{array}{l}\mathrm{Mg} \\
29.83\end{array}$} & \multirow{2}{*}{$\begin{array}{l}\mathrm{K} \\
31.5\end{array}$} & \multirow{2}{*}{$\begin{array}{c}\mathrm{HCO} 3 \\
1172\end{array}$} & \multirow{2}{*}{$\begin{array}{l}\mathrm{Cl} \\
27.9\end{array}$} & \multirow[t]{2}{*}{$\mathrm{CO}_{3}$} & \multirow[t]{2}{*}{$\mathrm{SO}_{4}$} & \multirow{2}{*}{$\begin{array}{l}\mathrm{F} \\
0.9\end{array}$} & \multirow{2}{*}{\multicolumn{2}{|c|}{$\begin{array}{cc}\mathrm{NO}_{3} & \mathrm{NO}_{2} \\
& \\
& 4.8\end{array}$}} & \multirow{2}{*}{$\begin{array}{c}\text { TDS } \\
1581\end{array}$} & \multirow{2}{*}{$\begin{array}{r}\mathrm{pH} \\
6.5\end{array}$} \\
\hline 61 Ambo town & & TS & 268.1 & & & & & & & & & & & & \\
\hline 62 Gonder town & Author, 2000 & $\mathrm{BH}$ & 20 & 48 & 22 & 0.1 & 268 & 7.0 & & 10.0 & 0.2 & 27.5 & & 322 & 7.1 \\
\hline 63 Mekele, town & Author, 2000 & $\mathrm{BH}$ & 13.7 & 236 & 128 & 0.1 & 219.5 & 56.7 & & 480.0 & 0.4 & 3.7 & & 974 & 7.6 \\
\hline 64 Assela & Author, 1998 & $\mathrm{BH}$ & 15 & 33.7 & 8.8 & 4.3 & 134.2 & 5.3 & & 0.1 & 1.5 & & & & 7.4 \\
\hline 65 Kersa & Author, 1998 & $\mathrm{BH}$ & 25 & 13 & 4 & 2 & 139 & 4.0 & & 1.0 & 0.6 & & & & 7.7 \\
\hline 66 Shoa Robit & Author, 2002 & $\mathrm{BH}$ & 47.0 & 53.1 & 14.8 & 3.9 & 320 & 22.6 & & 42.7 & 0.8 & & 8.0 & 513 & 7.3 \\
\hline 67 Bati, Wollo & Author, 2002 & $\mathrm{BH}$ & 67.9 & 119.0 & 39.0 & 0.5 & 457.5 & 85.6 & & 54.9 & & & 128.4 & 953 & 7.3 \\
\hline 68 El Wuha & Author, 2002 & $\mathrm{BH}$ & 200 & 21.61 & 13.18 & 4.47 & 464 & 51.1 & & 110.9 & & & 68.9 & 934 & 7.7 \\
\hline 69 Mille town & Author, 2002 & $\mathrm{BH}$ & 97.51 & 36.28 & 16.17 & 3.99 & 250 & 40.3 & & 69.3 & 0.7 & & 7.6 & 547 & 8.3 \\
\hline 70 Logia total & Author, 2002 & $\mathrm{BH}$ & 550.1 & 58.0 & 4.3 & 4.2 & 45.75 & 1025.1 & & 326.8 & 1.6 & & 0.0 & 2016 & 8.5 \\
\hline 71 Asayita & Author, 2002 & $\mathrm{BH}$ & 350.5 & 4.32 & 3.16 & 11.9 & 518.5 & 183.1 & & 152.1 & 1.9 & & 28.8 & 1254 & 8.2 \\
\hline 72 Hadi Buri, Gamari & Author, 2002 & $\mathrm{BH}$ & 1907.0 & 50.5 & 61.3 & 63.7 & 1083 & 2241.3 & & 741.6 & & & 147.7 & 6296 & 8.3 \\
\hline 73 Dubti & Author, 2002 & $\mathrm{BH}$ & 326.2 & 15.8 & 6.7 & 4.8 & 366 & 273.0 & & 246.1 & 1.6 & & 17.8 & 1258 & 7.9 \\
\hline 74 Logia & Author, 2002 & $\mathrm{BH}$ & 337.8 & 39.0 & 9.4 & 5.9 & 20 & 287.7 & & 367.1 & & & 8.6 & 1075 & 8.1 \\
\hline 75 Barda, Amibara & Author, 2002 & $\mathrm{BH}$ & 203.7 & 9.01 & 5.58 & 16.7 & 456 & 59.0 & & 46.7 & 3.8 & & 7.7 & 808 & 8.2 \\
\hline 76 Gewane & Author, 2002 & $\mathrm{BH}$ & 541.4 & 8.3 & 6.3 & 29.4 & 473 & 506.2 & & 485.2 & 2.4 & & 24.7 & 2077 & 8.2 \\
\hline 77 Nekemt & Author, 2002 & $\mathrm{BH}$ & 1.6 & 10.3 & 2.7 & 1.5 & 41 & 2.3 & & & 0.1 & & 5.0 & 65 & 6.3 \\
\hline 78 Bedolali, Amibara & Author, 2002 & $\mathrm{BH}$ & 221.7 & 2.62 & 1.71 & 2.75 & 288 & 64.2 & & 54.6 & 4.0 & & 4.9 & 698 & 8.4 \\
\hline 79 Awash Arba & Author, 2002 & $\mathrm{BH}$ & 55.56 & 53.13 & 14.41 & 7.92 & 351 & 31.3 & & 27.3 & 0.8 & & 7.9 & 549 & 7.7 \\
\hline $\begin{array}{l}\text { Matahara Sugar } \\
\text { Plantation }\end{array}$ & Author, 2002 & $\mathrm{BH}$ & 465.3 & 33.6 & 8.0 & 10.0 & 682 & 176.3 & & 144.2 & 9.1 & & 96.8 & 1625 & 7.4 \\
\hline 81 Goro & Author, 2002 & $\mathrm{BH}$ & 18.2 & 28.9 & 4.9 & 8.6 & 176.9 & 1.5 & & 3.2 & 0.0 & & 0.0 & 242 & 6.8 \\
\hline 82 Wolkite water supply & Author, 2002 & $\mathrm{BH}$ & 19.4 & 24.2 & 5.2 & 7.6 & 181 & 0.8 & & 1.0 & 1.0 & & 0.5 & 241 & 7.2 \\
\hline 83 Abelti, 200KM from AA & Author, 2002 & $\mathrm{BH}$ & 12.4 & 56.0 & 14.8 & 6.4 & 245 & 11.4 & & & 0.6 & & 24.6 & 371 & 7.3 \\
\hline 84 Bekel town & Author, 2002 & $\mathrm{BH}$ & 0.6 & 1.46 & 1.42 & 0.15 & 7 & 1.1 & & 0.3 & & & 4.2 & 16 & 5.6 \\
\hline $85 \begin{array}{l}\text { Aluto thermal gradient } \\
\text { well }\end{array}$ & Panichi,1995 & GW & 964.0 & 8.0 & 1.5 & 91.0 & 1543.0 & 501.0 & & 29.0 & & & & & 7.2 \\
\hline $86 \begin{array}{l}\text { Aluto deep geothermal } \\
\text { well }\end{array}$ & Panichi,1995 & GW & 1038.0 & 1.0 & 0.1 & 163.0 & 196.0 & 451.0 & & 111.0 & & & & & 7.0 \\
\hline 87 Tedecha & Author, 2002 & HW & 175.6 & 16.5 & 12.56 & 15.2 & 534 & 40.7 & & 49.6 & 2.1 & & 14.3 & 860 & 7.9 \\
\hline 88 Korke near Dessie & Author, 2002 & HW & 181 & 69.43 & 19.85 & 2.97 & 427 & 3.4 & & & & & 13.6 & 554 & 7.3 \\
\hline 89 Arsisi & Author, 2002 & HW & 183.8 & 9.19 & 5.39 & 4.98 & 346 & 51.1 & & 76.6 & 1.4 & & 18.9 & 697 & 8.1 \\
\hline $90 \begin{array}{l}\text { Awash on AA Jima } \\
\text { road }\end{array}$ & Author, 2002 & HW & 16.3 & 26.2 & 3.8 & 2.9 & 149 & 2.0 & & 3.2 & 0.4 & & & 204 & 7.6 \\
\hline 91 Wolkite & Author, 2002 & HW & 59.3 & 111.9 & 21.3 & 19.5 & 140.3 & 686.7 & & 102.3 & & & 25.5 & 1167 & 6.1 \\
\hline 92 Bedele town & Author, 2002 & HW & 1.9 & 11.5 & 1.4 & 1.66 & 46 & 1.2 & & 0.8 & 0.1 & & 5.3 & 70 & 6.1 \\
\hline 93 Loko, Dedesa Valley & Author, 2002 & $\mathrm{HW}$ & 8.48 & 3.5 & 0.88 & 0.88 & 35 & 0.4 & & 0.3 & 0.2 & & 1.1 & 51 & 6.2 \\
\hline 94 Kewisa, near Lekemt & Author, 2002 & HW & 1.4 & 5.8 & 1.6 & 1.11 & 21 & 0.9 & & 0.4 & & & 6.5 & 39 & 5.8 \\
\hline 95 Nekemt, town & Author, 2002 & HW & 3.7 & 6.7 & 2.7 & 1.3 & 42 & 4.3 & & & & & 19.1 & 80 & 6.5 \\
\hline 96 Ljaji town & Author, 2002 & HW & 20.6 & 26.8 & 7.6 & 7 & 36.6 & 26.8 & & 1.2 & 0.1 & & 122.4 & 249 & 6 \\
\hline
\end{tabular}

Note: $\mathrm{DW}=$ hand dug well, $\mathrm{HW}=$ hot wells, $\mathrm{BH}=$ borehole, $\mathrm{TS}=$ thermal spring, $\mathrm{CS}=$ cold spring, $\mathrm{R}=$ river, $\mathrm{L}=$ lake, $\mathrm{S}=\mathrm{swamp}$.

The hydrochemical signature of most of the lakes in the Ethiopian Rift is quite unique. This is attributed mainly to the amount and chemistry of the incoming and outgoing components of the hydrologic cycle. The mixing of different water types in the course of their evolution might have played a role, especially in terminal lake. The present day hydrochemical signature of the rift lakes result from the long geochemical and hydrochemical evolution of the lacustrine system throughout the Quaternary (UNDP, 1973). These lakes accumulated solutes from inflowing rivers, rainfall and groundwater sources. Subsequent evaporative concentration (especially in closed terminal lakes) led to the precipitation of minerals and this profoundly affected the composition of the remaining water. The present day composition of the terminal lake waters is therefore particularly difficult to interpret on the basis of present inflow and evaporation.

The fresh water lakes with less salinity in the rift are Ziway, Awassa and Abaya (the largest lake in the MER). Only slightly more saline are Langano and Chamo. Ziway, Langano and Abaya have substantial inflow from rivers, surface outflows and additional subsurface leakage (Halcrow, 1989; Tenalem Ayenew, 2001). Lake Chamo probably has a periodic overflow as well. Lake Awassa, which has an even higher surface elevation than Lake Ziway, must have substantial subsurface outflow to maintain its freshness. The outflow of the enriched lake water $\left(2 \mathrm{H}\right.$ and $\left.{ }^{18} \mathrm{O}\right)$ was detected in deep boreholes in the direction of outflow (Darling et al., 1996; Tenalem Ayenew, 2003). Lakes Abiyata and Shala are apparently terminal and are much more saline. 
The aridity and lack of flushing from high rainfall and surface runoff made many of the lakes in the northern MER and the Afar highly concentrated. The exception to this is the expanding Lake Beseka which underwent substantial dilution due to substantial groundwater flow from the surrounding over-irrigated mechanized farms (Elizabeth Kebede et al., 1996; Zenaw Tessema, 1996; WWDSE, 2000; 2001) due to the introduction of water from surrounding irrigation fields, which uses the Awash River. The most exceptional lake in the Afar is Lake Afdera, which is located at about 80 meters below sea level. It is extremely saline; with electrical conductivity of $250,000 \mu \mathrm{S} / \mathrm{cm}$ and pH 6.55 (Abebe Getahun, 2001).

The $\mathrm{pH}$ of the rift valley groundwater and nonsaline lakes generally range from 7 to 9 . However, deep geothermal waters and highly alkaline lakes may have values out of this range as in the case of Lake Afdera. In terms of ionic species high $\mathrm{Na}$, $\mathrm{CHO}_{3}$ and $\mathrm{F}$ characterize the MER. This is especially the case in thermal waters (Berhanu Gizaw, 1996). The lakes have also high $\mathrm{Na}, \mathrm{CHO}_{3}$ and $\mathrm{F}$, though the mechanism of enrichment is different. The TDS of lakes Ziway and Awassa and swamps of Shallo and Shetemata is less than $1,000 \mathrm{mg} / 1$ while those of Abaya, Chamo and Langano fall between 1,000 and 2,000 mg/l. The most alkaline lakes (Chitu, Shala, Abiyata and many of lakes in Afar) have TDS ranging from 20,000 to $50,000 \mathrm{mg} / 1$ (Craig et al., 1977; Von Damm and Edmond, 1984; Tenalem Ayenew, 2003). Alkaline lakes are terminal, with the exception of Awassa, which has subsurface outflow to the north. The notable difference between the TDS of the lakes is a matter of balance in mass flux (Tesfaye Chernet, 1982; Halcrow, 1989; Dessie Nidaw, 1990; Tenalem Ayenew, 1998; Seifu Kebede, 1999). Those lakes with low inflow as compared to the outflow components of the water balance attain higher ionic concentrations. These are peculiarly terminal lakes such as Shala and Abiyata where they have almost no groundwater outflow. The only outflow is through evaporation, which makes the lakes more alkaline and with high TDS. These saline and alkaline lakes have the lowest $\mathrm{Ca}$ and $\mathrm{Mg}$ content.

The MER waters are rich in F, at times as high as $100 \mathrm{mg} / \mathrm{l}$ in groundwaters associated with geothermal fields and in highly alkaline lakes; for example the small crater lake Chitu close to Shala has $250 \mathrm{mg} / 1$ of F (Elzabeth Kebede et al., 1996). This is quite common in many East African Rift waters (Kilham and Hecky, 1973). However, high F does not characterize all the rift valley. The highest $F$ is localized within the Awassa and Ziway-Shala basins and parts of the northern MER. In ZiwayShala basin there are large differences in $F$ concentration among the various water bodies; 1.9 to $250 \mathrm{mg} / \mathrm{l}$ for lakes, 2 to $150 \mathrm{mg} / 1$ for hot springs, from less than 0.1 to $64 \mathrm{mg} / 1$ for boreholes and 2 to $67 \mathrm{mg} / 1$ for Aluto geothermal wells around Langano (Berhanu Gizaw, 1996; Tenalem Ayenew, 1998).

Generally rivers, streams and swamps are of low salinity, F and TDS, except where they are influenced by the discharge of thermal springs or where they drain lakes. For example the Horakelo river flowing between lakes Langano and Abiyata and the Bulbula river connecting lakes Ziway and Abiyata have exceptionally high ionic concentration, which are similar to the source lakes (Table 2). With some exceptions, the rivers in the MER are short in length (less than $50 \mathrm{~km}$ ) and of comparatively low volumetric flow in part due to feeding the rift groundwater system through large step-faults and loose alluvial and lacustrine sediments. However, they are important sources of lake water (Katar, Meki, Awash, Bilate). The chemical composition of all these river waters indicate low TDS, usually dominated by $\mathrm{Na}$ and $\mathrm{HCO}_{3}$ but still containing important amounts of $\mathrm{K}$, $\mathrm{Ca}$ and $\mathrm{Mg}$, particularly in the Ziway-Shala basin. There is in fact a clear evidence of evaporative concentration between the upstream and downstream sites (Tenalem Ayenew, 1998).

As stated in the classical paper of Chebotarev (1955), groundwater tends to evolve chemically toward the composition of seawater. This evolution is normally accompanied by the following regional changes in dominant anion species.

$$
\begin{aligned}
& \mathrm{HCO}_{3}^{-} \rightarrow \mathrm{HCO}_{3}^{-}+\mathrm{SO}_{4}^{2-} \rightarrow \mathrm{SO}_{4}^{2-}+\mathrm{HCO}_{3}^{--} \rightarrow \\
& \mathrm{SO}_{4}^{2-}+\mathrm{Cl}^{-} \rightarrow \mathrm{Cl}^{-}+\mathrm{SO}_{4} 4^{--} \rightarrow \mathrm{Cl}
\end{aligned}
$$

This chemical evolution is evident in the Awash river basin where $\mathrm{HCO}_{3}$ dominates in the central MER and the plateaux and changes to $\mathrm{SO}_{4}$ type in the northern MER and then finally to $\mathrm{Cl}$ type in southern and central Afar. This dynamics of the regional groundwater behaviour has been independently shown by environmental isotopic studies (Craig et al., 1977; Panichi, 1995; Tenalem Ayenew, 2003).

From Table 2, in places, it is evident that $\mathrm{Cl}$ and $\mathrm{NO}_{3}$ content do not show systematic spatial variations. This indicates variations in the concentration of certain ions due to local lithological and geochemical controls and human influences instead of general ionic enrichment represented by increasing trend in TDS. The spatial variations are 
clearly demonstrated in the Piper Trilinear diagram (Fig. 3). Waters having TDS greater than $1500 \mathrm{mg} / 1$ and high $\mathrm{Cl}$ value (greater than 55 $\mathrm{mg} / \mathrm{l}$ ) are dominantly localized in the Afar and boreholes in the MER urban centres and few terminal lakes. Waters with F greater than $15 \mathrm{mg} / 1$ are localized in central and northern MER; those with very high TDS and F are terminal lakes and thermal waters in the MER. Waters with $\mathrm{HCO}_{3}$ greater than $2000 \mathrm{mg} / \mathrm{l}$ are mostly thermal waters around Langano and Shala and terminal lakes. The $\mathrm{NO}_{3}$ plot shows quite high pollution in many water samples, mainly in Addis Ababa area and the rift valley towns such as Ziway, Meki, Nazreth, Wonji and Methara. Figure 3 clearly demonstrates that the scattering in $\mathrm{HCO}_{3}$ is quite limited, indicating its dominance over other anions in most of the study area.

\section{CONCLUSION}

This study has clearly demonstrated the wide spatial variations of the hydrochemistry of natural waters in the extensive volcanic terrain of Ethiopia on the basis of extensive water sampling campaign supplemented by scattered previous hydrochemical records. It is believed that the research result will play a positive role in future water resources studies and development, which at the moment is at its infancy.

The clear spatial variation in the ionic concentration of both groundwater and surface water systems in the volcanic terrain of Ethiopia is owing to differences in rock-water interactions related to lithology and groundwater residence time, geomorphological setting and climate.

The TDS increases from the highlands to the rift valley following the regional groundwater flow directions towards areas of low rainfall and high evaporation and groundwater residence time. In contrast with the rift valley waters, the highland waters are more homogeneous in their chemical composition and are characterized by low TDS.

Highland waters are dominantly Ca-Mg bicarbonate type except few waters with high $\mathrm{SO}_{4}$ content in central Tigray where Mesozoic sedimentary rocks are outcropping associated with Tertiary volcanics. The rift valley waters are mainly Na-bicarbonate type with very high TDS and $F$. The escarpment waters are mixed type with moderate TDS. The high F in the rift is related to the dominance of acid volcanics, high temperature in geothermal fields associated with high $\mathrm{CO}_{2}$ out gassing probably incorporating $\mathrm{F}$.
In view of the general similarity of rock types drained by streams and rivers in highland volcanic province the major ion chemistry of surface waters is not significantly different from the shallow groundwater system of the same region.

The groundwaters tend to change from $\mathrm{HCO}_{3}$ to $\mathrm{SO}_{4}$ and then $\mathrm{Cl}$ type all the way from the MER to the Afar in the direction of regional surface water and groundwater flow directions and decrease in altitude. This is peculiar hydrochemical evolution of natural waters in big river basins.

Unlike the highland lakes and rivers, the rift lakes have exceptionally high ionic concentration with extreme variability both in the TDS and type of major ions. The closed-basin and terminal lakes attain the highest salinity, alkalinity and F concentrations as a result of subsequent evaporation. The dominant cation in almost all rift lakes is $\mathrm{Na}$.

There are few waters in major urban centres of the rift including Addis Ababa areas, which have high $\mathrm{NO}_{3}$ indicating antheropogenic pollutions.

\section{ACKNOWLEDGEMENTS}

I am grateful to the Department of Earth Sciences, Addis Ababa University for the field logistic support in the course of data collection for quite long time. I am also indebted to the Ethiopian Geological Surveys Central Laboratory for analysing some of the water samples and the Geothermal Exploration Project for providing some raw data. My thanks goes to SABA Engineering Central Laboratory for analysing some water samples and providing original raw data on the chemistry of some waters in the northern MER, central and north-western plateau and in the Bale region.

\section{REFERENCES}

1. Abebe Getahun (2001). Lake Afdera: A threatened saline lake in Ethiopia. SINET: Ethiop. J. Sci. 24(1):127-131.

2. Abdelwassie Hussien (2000). Hydrogeology of the Aynalem well field, Tigray, Northern Ethiopia. Unpublished MSc thesis, Addis Ababa University, 103 pp.

3. Ashley, R.P. and Burley, M.J. (1994). Controls on the occurrence of fluoride in groundwater in the rift valley of Ethiopia. In: Groundwater Quality, pp. 45-54, (Nash, H. and McCall, G.J.H., eds). Chapman and Hall, London.

4. Barberi, F., Ferrara, G., Santacroce, R. and Varet, J. (1975). Recent volcanic units of afar and their structural significance. In: Afar Depression of Ethiopia, pp. 38-54, (Pilger, A. and Roesler, A., eds). Schweizerbart. 
5. Baxter, R.M., Prosser, M.V., Talling, J.F. and Wood, R.B. (1965). Stratification in tropical African lakes at moderate altitudes. Limnol. Oceano. 10:511-520.

6. Berhanu Gizaw (1996). The origin of high bicarbonate and fluoride concentrations in waters of the Main Ethiopian Rift Valley, East African Rift system. J. Afr. Earth Sci. 22(4):391-402.

7. Chebotarev, I.I. (1955). Metamorphism of natural waters in the crust of weathering. Geochim. Cosmochim. Acta. 8:22-48, 137-170, 198-212.

8. Craig, H. (1977). Isotope geochemistry and hydrology of geothermal waters in the Ethiopian Rift Valley. Scripps Insi. Oceanography, ept. 77-14, 140 pp.

9. Craig, H., Lupton, J.E. and Horowiff, R.M. (1977). Isotope geochemistry and hydrology of geothermal-waters in the Ethiopian Rift Valley. Scripps Inst. of Oceanography. ept. 77-14, 160 pp.

10. Darling, W.G., Berhanu Gizaw, and Arusei, M.K. (1996). Lake-groundwater relationships and fluid-rock interaction in the African rift valley: Isotopic evidence. Journal of African Earth Sciences 22:423-431.

11. Dessie Nidaw (1990). Hydrogeology of Awassa Area. MSc thesis, Addis Ababa University, 106 pp.

12. Elizabeth Kebede, Zinabu Gebremariam and Ahlgren, A. (1996). The Ethiopian Rift Valley lakes: Chemical characteristics along a salinityalkalinity series. Hydrobiologia 288:1-12.

13. Ellis, A.J. and Mahon, W.A.J. (1977). Chemistry and Geothermal Systems . Academic Press.

14. EMA (1988). National Atlas of Ethiopia. Ethiopian Mapping Authority, Addis Ababa, Ethiopia.

15. Fournier, R.O. and Truesdell, A.H. (1970). Chemical indicators of subsurface temperature applied to hot spring waters of Yellowstone National Park, Wyoming, USA. Geothermics Special Issue 2:529-535.

16. Freeze, R.A. and Cherry, J.A. (1979). Groundwater. Prentice-Hall, Englewood Cliffs, N.J., USA, 604 pp.

17. Gasse, F. (1980). Lat Quaternary changes in the lake levels and diatom assemblages on the southeastern margin of the Sahara. Paleoecology of Africa 11:117-134.

18. Gerasimovskiy, V.L. and Savinova, Y.N. (1969). Fluorine contents of volcanic rocks in the rift zone of East Africa. Geochemistry International 6:1124-1128.

19. Giday Woldegebriel, Aronson, J.L. and Walter, R.C. (1990). Geology, geochronology, and rift basin development in central sector of the Main Ethiopian Rift. Geological Society of America Bulletin 102:439-458. [B34.022].
20. Halcrow (1989). Rift Valley Lakes Integrated Natural Resources Development Master Plan. Ethiopian Valleys Development Studies Authorities, Unpub. Report.

21. Hem, J.D. (1970). Study and interpretation of the chemical characteristics of natural waters, US. Geol. Surv. Water Supply Paper 1473, 363 pp.

22. Kazmin, V., Seifemichael Berhe, Nicoletti, M. and Petrucciani, C. (1980). Evolution of the northern part of the Ethiopian rift. Atti Convegni Lincei 47:275-292.

23. Kilham, P. and Hecky, R.E. (1973). Fluoride: geochemical and ecological significance in East African waters and sediments. Limnol. Oceanogr. 18:932-945.

24. Lemessa Mekonta (2001). Hydrogeological controls in sandstone of Ambo area. Unpub. MSc thesis, Addis Ababa University, 115 pp.

25. Lofeller, H. (1978). Limnological and paleolimnological data on the Bale Mountain lakes (Ethiopia). Verh. int. Verein. Limnol. 20:1131-1138.

26. Mesfin Sahle (2001). Hydrogeological investigation of the Upper and Middle Borkena river catchment, northern Ethiopia (Wollo). Unpub. MSc thesis, Addis Ababa University, 144 pp.

27. Molla Demellie (2000). Hydrology, hydrogeology and hydrochemistry of the lakes system HaiqArdibo, Northern Ethiopia. Unpub. MSc thesis, Addis Ababa University, 135 pp.

28. Mohr, P. (1970). The Geology of Ethiopia. Addis Ababa University Press, 268 pp.

29. Mohr, P. (1983). Ethiopian flood basalt province. Nature 303:577-584.

30. Panichi, C. (1995). Isotopic investigation in geothermal hydrology. Mission report code 2010. 5250, 131. C300020389, F2E. Submitted to the isotopic hydrology section of the International Atomic Energy Agency, Vienna.

31. Peccerillo, A. and Gezahegn Yirgu (1996). Geochemical behaviour of fluorine in the volcanic systems of the Ethiopian Rift Valley: Implications for the problem of high fluorine waters (abstract). In: Program and Abstracts of the third Ethiopian Geosciences and Mineral Engineering Congress, 15-17 November, Addis Ababa.

32. Pik, R., Deniel, C., Coulon, C., Gezahegn Yirgu, Hofmann, C. and Dereje Ayalew (1998). The northwestern Ethiopian Plateau flood basalts. Classification and spatial distribution of magma types. Journal of Volcanology and geothermal Research 81:91-111.

33. Seifu Kebede (1999). Hydrology and hydrochemistry of Bishoftu crater lakes (Ethiopia): Hydrogeological, hydrochemical and oxygen isotope modeling. Unpub. MSc thesis, Addis Ababa University, 127 pp. 
34. Solomon Tale (2000). The extent of surface water and groundwater pollution. Unpub. MSc thesis, Addis Ababa University, 135 pp.

35. Street, F.A. (1979). Late Quaternary Lakes in the Ziway-Shala Basin, Southern Ethiopia. (UK). PhD thesis [Quaternaire: STR-80.094].

36. Talling, J.F. and Talling, I.B. (1965). The chemical composition of African lake waters. Int. Rev. Ges. Hydrobiolgia 50:421-463.

37. Tenalem Ayenew (1998). The hydrogeological system of the lake district basin, Central Main Ethiopian Rift. PhD thesis, Free University of Amsterdam, 259 pp.

38. Tenalem Ayenew (2001). Numerical groundwater flow modelling of the central Main Ethiopian Rift lakes basin. SINET: Ethiop. J. Sci. 24(2):167184.

39. Tenalem Ayenew (2003). Environmental isotopebased integrated hydrogeological study of some Ethiopian rift lakes. Journal of Radioanalytical and Nuclear Chemistry, Vol. 257, No. 1., 11-16 pp.

40. Tesfaye Chernet (1982). Hydrogeologic map of the lakes region (with memo). Ethiopian Institute of Geological Surveys, Addis Ababa, Ethiopia.

41. Tesfaye Chernet (1993). Hydro-geology of Ethiopia and Water Resource Development. (Unpublished Report). Geological Survey of Ethiopia, Addis Ababa, 222 pp.

42. Tesfaye Chernet, Travi, Y. and Valles, V. (2001). Mechanism of degredation of the quality of natural water in the lakes region of the Ethiopian Rift Valley. Wat. Res. 35(12):28192832.
43. Teshome Dechassa (1999). Water balance and effect of irrigated agriculture on groundwater quality in the Wonji area, Ethiopian Rift valley. Unpub. MSc thesis, Addis Ababa University, 136 pp.

44. UNDP (1973). Investigation of geothermal resources for power development: Geology, geochemistry and hydrology of hot springs of the East African Rift System within Ethiopia (with maps), New York.

45. Von Damm, K.L. and Edmond, J.M. (1984). Reverse weathering in the closed basin lakes of the Ethiopian Rift. Amer. J. Sci. 284:835-862.

46. Wood, R.B. and Talling, J.F. (1988). Chemical and algal relationship in a salinity series of Ethiopian inland waters. Hydrobiologia 158:2967.

47. WWDSE (2000). Study of Lake Beseka, Final Report Vol. I. Water Works Design and Supervision Enterprise, Addis Ababa, 220 pp.

48. WWDSE (2001). The study of lake Awassa level rise. Southern Nations Nationalities and Peoples Regional State. Water, Mines and Energy Resources Development Bureau. Unpublished report of the Water Works Design and Supervision Enterprise (main report volume II), Addis Ababa, Ethiopia, 291 pp.

49. Zanettin, B. (1993). Evolution of the Ethiopian volcanic province. Atti della Accademia Nazionale dei Lincei. Mem. Fis. Acc. Lincei. S. 9, V. 1:153-181, Roma, Italy.

50. Zenaw Tessema (1996). Hydrochemical and water balance approach in the study of high water level rise of lake Beseka. MSc thesis, The University of Birmingham, $90 \mathrm{pp}$. 